\title{
LEGUMINOSAE EM DOIS FRAGMENTOS DE FLORESTA ESTACIONAL Semidecidual em Araponga, Minas Gerais, Brasil: ARBUSTOS, SUBARBUSTOS E TREPADEIRAS ${ }^{1}$
}

\author{
José Martins Fernandes ${ }^{2,3,4}$ \& Flávia Cristina Pinto Garcia ${ }^{2}$
}

\section{Resumo}

(Leguminosae em dois fragmentos de floresta estacional semidecidual em Araponga, Minas Gerais, Brasil: arbustos, subarbustos e trepadeiras) É apresentado o estudo taxonômico dos arbustos, subarbustos e trepadeiras de Leguminosae em dois fragmentos de Floresta Estacional Semidecidual em Araponga, próximo ao Parque Estadual da Serra do Brigadeiro (PESB). A coleta do material botânico foi realizada entre agosto de 2005 e setembro de 2006, durante visitas mensais ao entorno e interior de dois fragmentos florestais. Foram amostrados 21 táxons, distribuídos em 13 gêneros. O gênero com maior número de espécies foi Desmodium (4 spp.), seguido por Chamaecrista, Senna, Mimosa, Centrosema e Crotalaria (2 spp. cada). O hábito subarbustivo foi o mais representado com 13 espécies. O estudo apresenta chave, descrições e ilustrações dos táxons, comentários sobre taxonomia, fenologia, distribuição geográfica e hábitat.

Palavras-chave: Leguminosae, taxonomia, Floresta Atlântica, Zona da Mata Mineira, inventário florístico.

\section{Abstract}

(Leguminosae in two fragments of the estacional semidecidual forest fragments in Araponga, Minas Gerais, Brasil: shrubs, subshrubs and vines) The present study focussed on shrubs, subshrubs and vines belonging to the Leguminosae in two Seasonal Semidecidual Forest fragments in Araponga, near the Parque Estadual da Serra do Brigadeiro (PESB). Collections were carried out between August 2005 and September 2006, in monthly visits to the two sites and their surroundings. Twenty one taxa were found, distributed amongst 13 genera, of which the largest was Desmodium (4 spp.), followed by Chamaecrista, Senna, Mimosa, Centrosema and Crotalaria. ( 2 spp. each). The most frequent habit was subshrubby, found in 13 species. The study presents identification key, descriptions and illustrations of taxa, as well as data on their phenology, distribution and habitat.

Key words: Leguminosae, taxonomy, Atlantic Forest, Zona da Mata Mineira, floristic survey.

\section{INTRODUÇão}

Leguminosae é considerada a terceira maior família de angiospermas, com 727 gêneros e 19.325 espécies, distribuídas em três subfamílias: Caesalpinioideae, Mimosoideae e Papilionoideae (Lewis et al. 2005). No Brasil, ocorrem cerca de 188 gêneros e 2.100 espécies (Lima 2000). Tratase de uma família cosmopolita, ocorrendo desde os picos das serras montanhosas até o litoral arenoso, da floresta tropical úmida até desertos, inclusive em ambientes aquáticos, mas os centros de diversidade diminuem a partir do distanciamento da linha do Equador (Lewis 1987). No Brasil, figura entre as principais famílias que compõem a flora dos diversos ecossistemas (Souza \& Lorenzi 2005).

Apresentam-se como ervas anuais ou perenes, eretas, prostradas, difusas, trepadeiras, lianas, subarbustos, arbustos e árvores de pequeno, médio ou grande porte (Lewis 1987). A família é monofilética e apresenta as seguintes sinapomorfias: folhas compostas, alternas, com pulvino; pétala adaxial diferenciada e ovário monocarpelar

Artigo recebido em 10/2007. Aceito para publicação em 04/2008.

${ }^{1}$ Parte da Dissertação de Mestrado do primeiro autor, Programa de Pós-Graduação em Botânica, Universidade Federal de Viçosa, Minas Gerais, Brasil.

${ }^{2}$ Departamento de Biologia Vegetal da Universidade Federal de Viçosa, Avenida P. H. Rolphs s/no, 36571-000, Viçosa, MG, Brasil.

${ }^{3}$ Bolsista do Conselho Nacional de Desenvolvimento Científico e Tecnológico - CNPq

${ }^{4}$ Autor para correspondência: fernanbio@bol.com.br, fcgarcia@ufv.br 
(Chappill 1995). Os frutos são geralmente do tipo legume mas apresentam variações: legume bacóide, nucóide e samaróide, e também lomento, folículo, sâmara e drupa (Barroso et al. 1999).

No Brasil, os estudos sobre comunidades de herbáceas e arbustos florestais ainda são escassos (Müller \& Waechter 2001). Para Richards (1952), o conhecimento da estrutura e composição dos estratos inferiores de florestas pode fornecer dados importantes sobre as condições ambientais e o estado de conservação da vegetação.

Os estudos taxonômicos realizados com Leguminosae em florestas estacionais semideciduais em Minas Gerais, mostraram a grande diversidade da família nesse tipo de vegetação (Mendonça-Filho 1996; Bortoluzzi et al. 2003, 2004; Filardi et al. 2007; Lima et al. 2007). Em estudos florísticos do estrato arbóreo, Oliveira-Filho (2006) citou Leguminosae com uma das principais famílias em número de espécies para o estado. Saporetti-Júnior (2005) e Soares et al. (2006) em estudo fitossociológico do estrato arbóreo no município de Araponga, citaram a família como uma das principais na composição florística e na estrutura da vegetação na região.

Devido à importância de Leguminosae na composição florística e estrutural da vegetação na região de Araponga, este trabalho teve como objetivos: realizar o estudo taxonômico das espécies de Leguminosae subarbustivas, arbustivas e trepadeiras, ocorrentes em dois fragmentos florestais no município de Araponga, Minas Gerais; fornecer chave, descrições e ilustrações dos gêneros e táxons específicos e infra-específicos, comentários sobre taxonomia, distribuição geográfica, hábitat e fenologia.

\section{Material e Métodos}

O levantamento florístico foi realizado em dois fragmentos florestais localizados entre os meridianos $42^{\circ} 32^{\prime}$ e $42^{\circ} 27^{\prime} \mathrm{W}$ e os paralelos $20^{\circ} 38^{\prime}$ e $20^{\circ} 43^{\prime}$ S (Fig. 1), no município de Araponga, Zona da Mata, sudeste de Minas Gerais, no entorno do Parque Estadual da Serra do Brigadeiro (PESB). São áreas particulares de cinco moradores locais, denominadas Fragmento daEva (3 ha) e Fragmento da Lurdinha (5 ha), estando a uma distância de 3,5 km do PESB, e que sofreram ao longo do tempo a exploração da madeira para uso familiar.

A vegetação pode ser caracterizada como Floresta Estacional Semidecidual, de acordo com a classificação de Veloso et al. (1991), e está inserida nos domínios da Floresta Atlântica. Na classificação de Köppen, o clima da região é caracterizado como de $\mathrm{Cw}_{\mathrm{b}}$ a $\mathrm{Cw}_{\mathrm{a}}$ (mesotérmico) caracterizado por verões brandos a quentes e úmidos com a temperatura média anual de $18^{\circ} \mathrm{C}$, sendo que no inverno, é de $10^{\circ} \mathrm{C}$; e no verão é de $23^{\circ} \mathrm{C}$ (ENGEVIX 1995). A precipitação anual varia de 1.200 a $1.800 \mathrm{~mm}$, com período chuvoso de novembro a março, e período seco de maio a setembro, sendo comum nas regiões mais altas a formação de neblina; o relevo é montanhoso com declividade variando de 20 a $45 \%$ nas encostas, com altitude média de 1.000 metros e a classe predominante de solo é o Latossolo (Golfari 1975).

Para a coleta do material botânico, foram realizadas visitas mensais aos fragmentos no período de agosto de 2005 a outubro de 2006. O sistema de classificação adotado para família, subfamílias e gêneros está de acordo com Lewis et al. (2005). A caracterização quanto ao hábito está de acordo com Guedes-Bruni et al. (2002). A terminologia adotada nas descrições morfológicas foi baseada em Radford et al. (1974), complementada com termos específicos obtidos em revisões dos gêneros e, para os tipos de frutos, foi utilizada a classificação de Barroso et al. (1999). As ilustrações foram realizadas com o auxílio de uma câmara clara acoplada a estereomicroscópio Zeiss, utilizando-se material rehidratado ou fixado em álcool $70 \%$. 


\section{Resultados e Discussão}

Nos fragmentos florestais amostrados no município de Araponga, foram encontrados 21 táxons de Leguminosae, entre subarbustos, arbustos e trepadeiras, distribuídos em 13 gêneros. Os gêneros com maior número de espécies foram Desmodium (4 spp.), seguido por Chamaecrista, Senna, Mimosa, Centrosema e Crotalaria (2 spp. cada). Aeschynomene, Camptosema, Cleobulia,
Indigofera, Rhynchosia, Stylosanthes e Zornia estão representados nas áreas por uma espécie cada. O hábito subarbustivo foi o mais representado com 13 espécies, seguido pelas trepadeiras e arbustos com cinco e três espécies, respectivamente. As espécies amostradas no estudo são de ampla distribuição, com exceção de Camptosema bellum que é restrita aos estados de Minas Gerais e Espírito Santo.

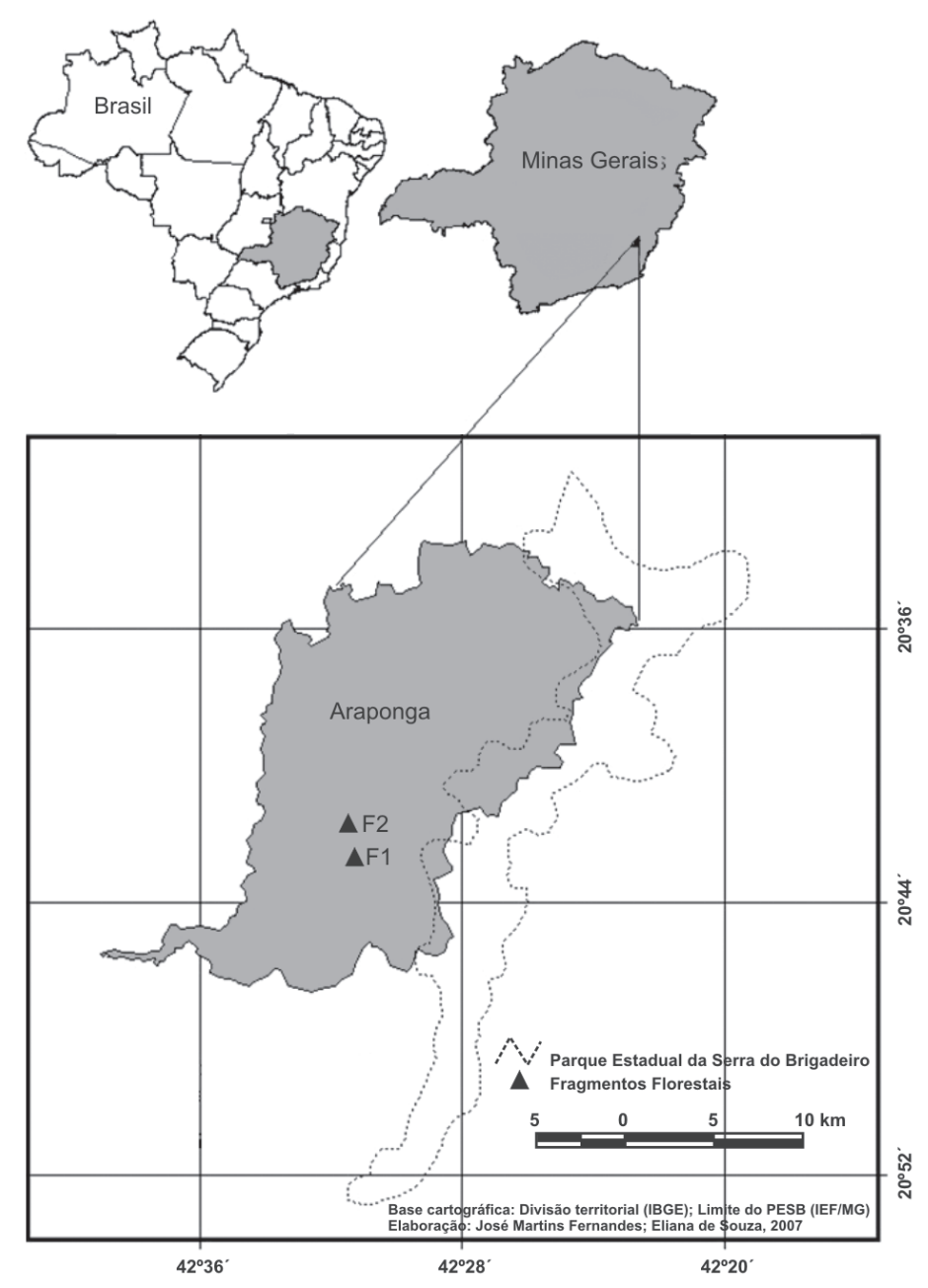

Figura 1 - Localização dos fragmentos de Floresta Estacional Semidecidual estudados no município de Araponga, Minas Gerais: F1 - Fragmento da Lurdinha e F2 - Fragmento da Eva. 


\section{Chave para identificação dos táxons de Leguminosae em fragmentos florestais em Araponga (MG): arbustos, subarbustos e trepadeiras}

1. Folhas uni-trifolioladas.

2. Folhas unifolioladas ou bifolioladas.

3. Folhas unifolioladas

3.5.1. Crotalaria breviflora

3'. Folhas bifolioladas.

4. Folíolos elípticos a lanceolados, pecíolo 1-1,5 cm compr. face adaxial glabra; fruto lomento 3.10. Zornia gemella

4'. Folíolos obovados, pecíolo $0,3-0,5 \mathrm{~cm}$ compr., face adaxial esparso-serícea; fruto legume 1.1.2. Chamaecrista rotundifolia var. rotundifolia

2'. Folhas trifolioladas.

5. Trepadeiras.

6. Folíolos laterais simétricos.

7. Flores não ressupinadas; cálice tubular, tetrâmero, avermelhado

3.2. Camptosema bellum

7'. Flores ressupinadas; cálice campanulado, pentâmero, esverdeado.

8. Folíolos terminais ovados a ovado-lanceolados; lacínios laterais inferiores do cálice menores que o tubo 3.3.1. Centrosema arenarium

8'. Folíolos terminais lanceolados, lacínios laterais inferiores do cálice maiores que o tubo 3.3.2. Centrosema virginianum

6'. Folíolos laterais assimétricos.

9. Folíolos terminais elípticos; corola lilás; legume não constricto entre as sementes 3.4. Cleobulia multiflora

9'. Folíolos terminais ovados; corola amarela; legume constricto entre as sementes 3.8. Rhynchonsia phaseoloides

5'. Arbustos ou subarbustos.

10. Estípula amplexicaule 3.9. Stylosanthes guianensis var. guianensis

10’. Estípula não amplexicaule.

11. Corola amarela; fruto legume inflado

3.5.2. Crotalaria incana

11'. Corola rosada, avermelhada ou arroxeada; fruto lomento.

12. Folíolos laterais assimétricos

3.6.2. Desmodium affine 12'. Folíolos laterais simétricos.

13. Folíolos terminais amplo-elípticos .. 3.6.1. Desmodium adscendens 13'. Folíolos terminais elípticos ou ovados.

14. Folíolos elípticos; estípulas soldadas; artículos do lomento oblongos .

3.6.3. Desmodium incanum

14'. Folíolos ovados; estípulas livres entre si; artículos do lomento triangulares

3.6.4. Desmodium uncinatum

1'. Folhas plurifolioladas.

15. Folhas pinadas.

16. Nectário foliar presente.

17. Folíolos obovados ou elípticos.

18. Folíolos com ápice arredondado; nectário na base do pecíolo; legume planocompresso 1.2.1. Senna cernua

18'. Folíolos com ápice retuso; nectário entre o primeiro par de folíolos; legume subcilíndrico 1.2.2. Senna pendula var. glabrata 
17'. Folíolos linear-oblongos

1.1.1. Chamaecrista nictitans var. disadena

16'. Nectário foliar ausente.

19. Folha paripinada; fruto lomento

3.1. Aeschynomene elegans

19'. Folha imparipinada; fruto legume

3.7. Indigofera suffruticosa

15'. Folhas bipinadas.

20. Pina 1 par; foliólulos 2 pares por pina.

2.1.2. Mimosa velloziana

20'. Pina 4-5 pares; foliólulos 13-17 pares por pina .......

2.1.1. Mimosa diplotricha

\section{Caesalpinioideae}

1.1. Chamaecrista Moench, Methodus 272. 1794.

Árvores, arbustos, subarbustos ou ervas. Folhas pinadas; estípulas presentes e estipelas ausentes; nectário foliar presente ou ausente no pecíolo ou entre os folíolos; folíolos opostos, raramente subopostos. Inflorescências racemosas, axilares, caulifloras, ramifloras ou supra-axilares; brácteas e bractéolas presentes, às vezes caducas; flores pentâmeras, zigomorfas ou levemente assimétricas; cálice dialissépalo, esverdeado ou amarelado; corola dialipétala, amarela; androceu dialistêmone, 5-10 estames férteis, iso ou heterodínamos; estaminódio às vezes presente; ovário pluriovulado. Fruto legume, deiscência elástica; semente com testa lisa ou pontuada.

\subsubsection{Chamaecrista nictitans var. disadena} (Steud.) H.S. Irwin \& Barneby, Mem. New York Bot. Gard. 35: 826. 1982 . Fig. 2 a-b

Subarbustos 30-40 cm alt.; ramos jovens vilosos. Estípulas 9-12 mm compr., lanceoladas, pubescentes, persistentes; pecíolo $4-5 \mathrm{~mm}$ compr., canaliculado, viloso; nectário foliar no pecíolo, caliciforme, estipitado; raque $3-5 \mathrm{~cm}$ compr., canaliculada, pubescente; folíolos 17 23 pares, $0,5-1,4 \times 0,1-0,2 \mathrm{~cm}$, linear-oblongos, ápice agudo, base assimétrica, face adaxial glabrescente, face abaxial pubescente. Pedúnculo 1-2 mm compr.; brácteas 4-5 mm compr., lanceoladas, pubescentes; bractéolas 2,5-2,8 mm compr., lanceoladas, pubescentes externamente; cálice 7-8,2 mm compr., pubescente externamente; corola ca. $2 \mathrm{~cm}$ compr.; estames 10, heterodínamos, 5 maiores, filetes $8-11 \mathrm{~mm}$ compr., anteras $5-6 \mathrm{~mm}$ compr., 5 menores, filetes $7-11 \mathrm{~mm}$ compr., anteras 3-3,1 mm compr., sem estaminódios; ovário 5,2-7 mm compr., levemente curvo, pubescente; estilete 3-4 mm compr., curvo, glabro; estigma lateral, truncado, ciliado. Legume 4,5-6×0,4-0,5 cm, plano-compresso, pubescente; 12-22 sementes, 3,3-4 × 1,8-2 $\mathrm{mm}$, oblongas, avermelhadas.

Material examinado: Fragmento da Lurdinha, 25.II.2006, fl. e fr., J. M. Fernandes 189 (VIC); 16.XII.2006, fl. e fr., J. M. Fernandes 413 (VIC).

Chamaecrista nictitans var. disadena distingue-se de $C$. rotundifolia var. rotundifolia por apresentar folíolos com 1723 pares, nectário foliar estipitado no pecíolo e corola com ca. $2 \mathrm{~cm}$ de comprimento, enquanto que a segunda variedade apresenta folhas com um par de folíolos, ausência de nectário foliar no pecíolo e corola de 5-5,7 mm de comprimento. A variedade ocorre no México, Panamá, Colômbia, Bolívia, Venezuela, Guiana, Suriname e Brasil. No Brasil, está distribuída nos estados de Roraima, Amapá, Amazonas, Ceará, Bahia e Minas Gerais (Irwin \& Barneby 1982). Nos fragmentos estudados, ocorrem em áreas abertas e antropizadas. Floresce de novembro a março e frutifica de dezembro a junho.

\subsubsection{Chamaecrista rotundifolia (Pers.)} Greene var. rotundifolia, Syn. Pl. 1: 456. 1805.

Fig. 2 c-e

Subarbustos $30-40 \mathrm{~cm}$ alt.; ramos jovens hirsutos. Estípulas 7-13 mm compr., lanceoladas, ciliadas, adpressas ao caule, persistentes; pecíolo 3-5 mm compr., canaliculado, pubescente; nectário foliar ausente; raque $2-3 \mathrm{~mm}$ compr., canaliculada, esparso-serícea; folíolos 2, 0,9-2,1 $\times 0,6-1,4 \mathrm{~cm}$, obovados, ápice emarginado a 

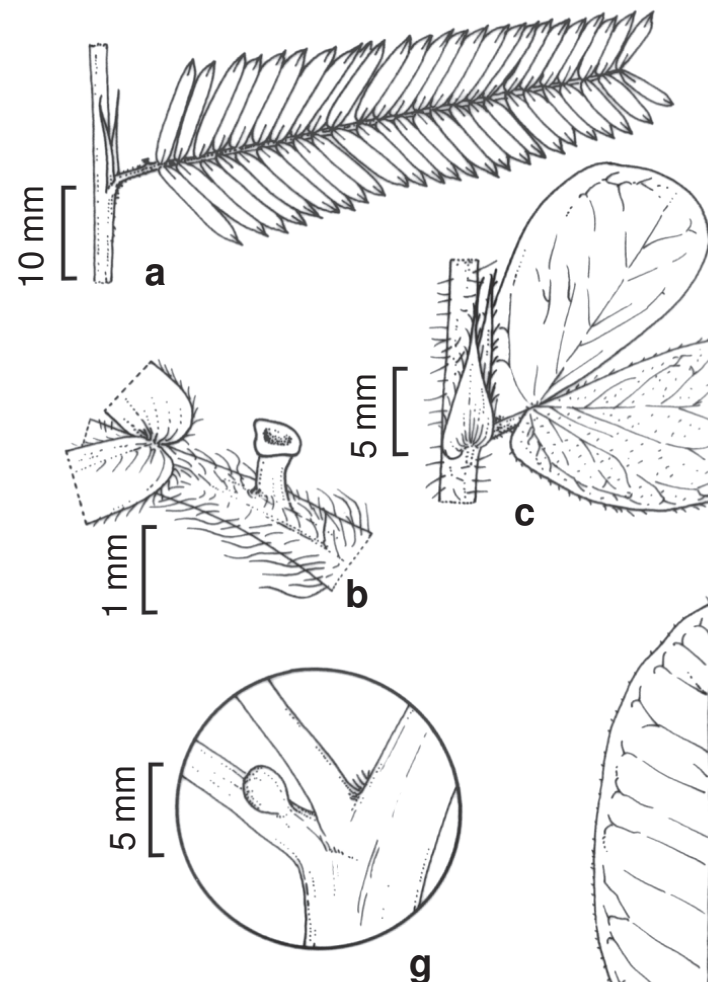

g

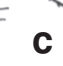

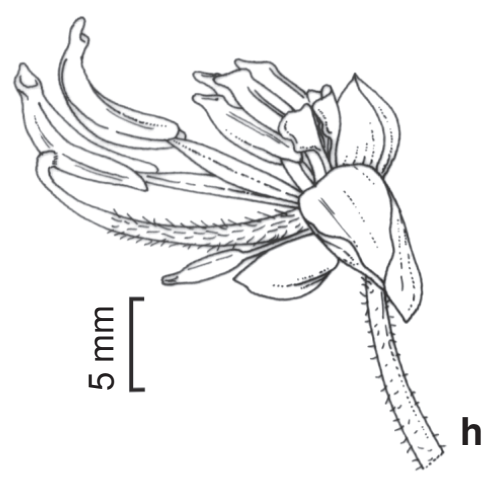
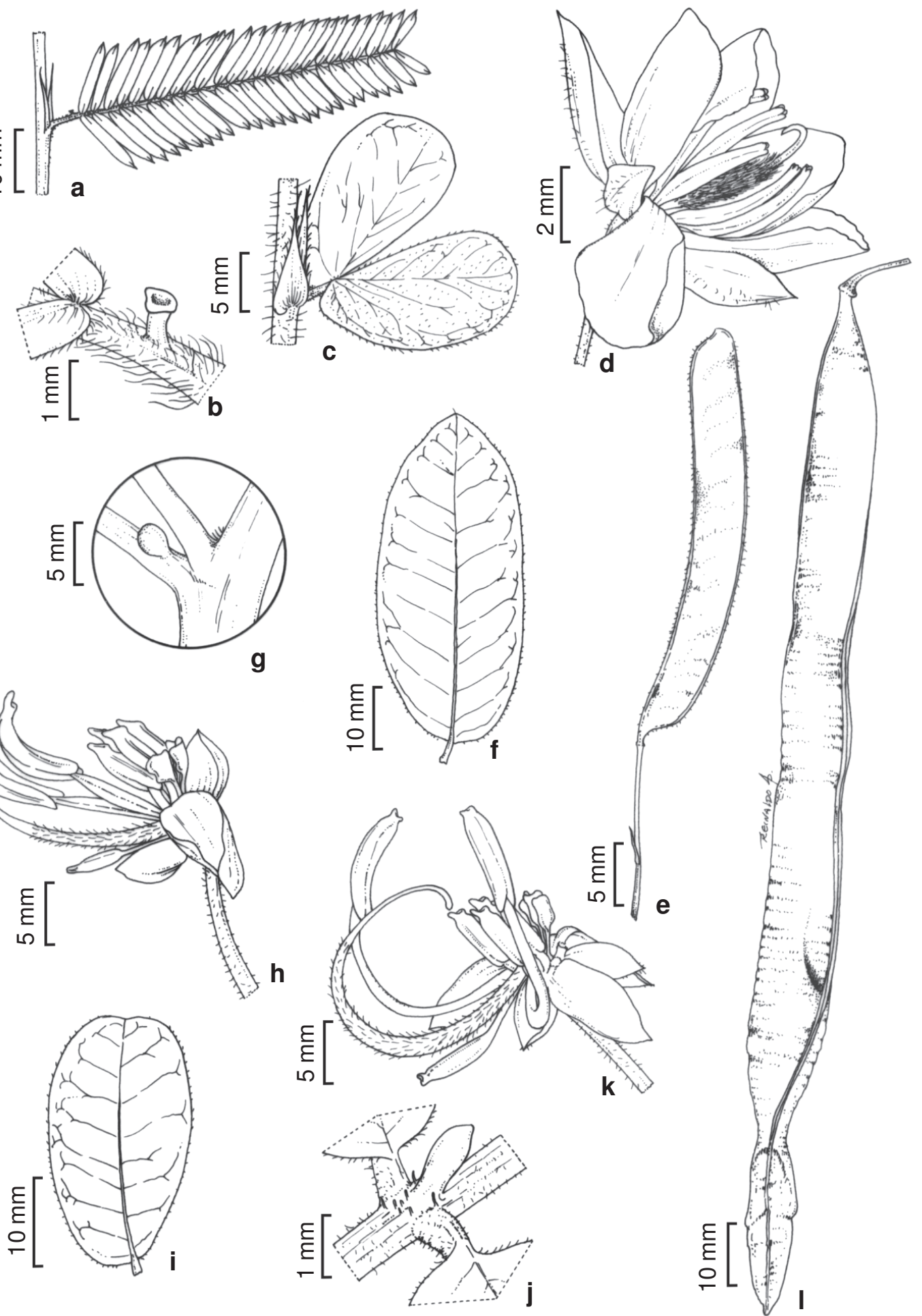

Figura 2 - a-b. Chamaecrista nictitans var. disadena - a. folha; b. nectário. c-e. C. rotundifolia var. rotundifolia -c. folha; d. flor; e. fruto. f-h. Senna cernua -f. folíolo; g. nectário foliar; h. flor sem pétalas. i-1. S. pendula var. glabrata - i. folíolo; j. nectário foliar; k. flor sem pétalas; 1. fruto. (a-b Fernandes 189; c-e Fernandes 172; f-h Fernandes 136; i-k Fernandes 263; 1 Fernandes 252) 
retuso, base oblíqua, faces adaxial e abaxial esparso-seríceas, margens ciliadas. Pedúnculo ausente; brácteas 1,3-1,5 $\mathrm{mm}$ compr., lanceoladas, glabrescentes; cálice 3,2-5 mm compr., pubescente externamente; corola 5$5,7 \mathrm{~mm}$ compr.; estames 5, isodínamos, 4,2$4,8 \mathrm{~mm}$ compr., anteras $3,2-3,6 \mathrm{~mm}$ compr., estaminódios 3; ovário ca. 3 mm compr., seríceo, reto; estilete 1,8-2 mm compr., curvo, glabro; estigma lateral, truncado, ciliado. Legume 2,3$3,3 \times 0,4 \mathrm{~cm}$, plano-compresso, esparso-hirsuto; 7-10 sementes, 3-3,2 × 1-1,5 mm, oblongas, acinzentadas.

Material examinado: Fragmento da Eva, 25.II.2006, fl. e fr., J. M. Fernandes 172 (VIC).

Está distribuída dos Estados Unidos (Flórida) até a Argentina. No Brasil, ocorre nos estados do Mato Grosso, Goiás, Maranhão, Tocantins, Paraná, Rio de Janeiro, Espírito Santo (Irwin \& Barneby 1982), São Paulo, Rio Grande do Sul (Bortoluzzi 2004) e Minas Gerais. Ocorre em cerrados, campos, áreas abertas e perturbadas, margens de estrada, florestas alteradas e pastagens (Irwin \& Barneby 1982). Está bem representada no entorno dos fragmentos em áreas alteradas ou não. Floresce de novembro a junho e frutifica de janeiro a setembro.

1.2 Senna Mill., Gard. Dict. Abr. (ed. 4) 3: 1754.

Árvores, arbustos ou subarbustos. Folhas pinadas; estípulas presentes, estipelas ausentes; nectário foliar presente no pecíolo ou entre os pares de folíolos, às vezes ausentes; folíolos opostos, raramente subopostos. Inflorescências racemosas ou paniculadas, multifloras até bifloras, axilares ou terminais; brácteas presentes e bractéolas ausentes; flores pentâmeras, zigomorfas ou levemente assimétricas; cálice dialissépalo, esverdeado ou amarelado; corola dialipétala, amarela; androceu dialistêmone, 7 estames férteis, heterodínamos, 3 maiores adaxiais, 4 menores medianos, 3 estaminódios abaxiais; ovário pluriovulado. Fruto legume bacóide, deiscente, raramente indeiscente; sementes compressas, geralmente areoladas.
1.2.1 Senna cernua (Balb.) H.S. Irwin \& Barneby, Mem. New York Bot. Gard. 35: 419. 1982.

Fig. 2 f-h

Subarbustos 60-80 cm alt.; ramos jovens esparso-seríceos. Estípulas 5-6 mm compr., lanceoladas, esparso-seríceas, decíduas; pecíolo 3-9,5 cm compr., cilíndrico, esparso-seríceo; nectário foliar cônico, na base do pecíolo; raque 10-17 cm compr., cilíndrica, esparso-serícea; folíolos 5-9 pares, 3-8,6×1,5-3,3 cm, elípticoobovados, ápice arredondado, base assimétrica, face adaxial glabra e abaxial serícea. Inflorescências racemosas, terminais; pedúnculo 0,7-1,5 mm compr.; raque $1,5-3 \mathrm{~cm}$ compr., estriada, esparso-serícea; brácteas 7-8,2 mm compr., lanceoladas, pubescentes; cálice 4-11 $\mathrm{mm}$ compr., pubescente externamente; corola $1,6-2 \mathrm{~cm}$ compr.; estames maiores 3 , filetes 8 $15 \mathrm{~mm}$ compr., anteras 5-8 $\mathrm{mm}$ compr., medianos 4 , filetes $2-3 \mathrm{~mm}$ compr., anteras 4 5 mm compr., estaminódios 3; ovário 13-15 mm compr., seríceo, curvo; estilete 2-3 mm compr., glabro, curvo; estigma terminal, truncado, ciliado. Legume $20-27 \times 0,4 \mathrm{~cm}$, plano compresso, esparso seríceo; 90 sementes, unisseriadas, $3 \times 1-2 \mathrm{~mm}$, elípticas, enegrecidas. Material examinado: Fragmento da Lurdinha, 27.I.2006, fl. e fr., J. M. Fernandes 136 (VIC); idem, fl. e fr., J. M. Fernandes 137 (VIC).

Senna cernua distingue-se de Senna pendula var. glabrata por apresentar pecíolo longo, de 3-9,5 cm comprimento, com um nectário basal cônico, folíolos 5-9 pares, elípticoobovados, frutos $20-27 \mathrm{~cm}$ comprimento, estreitos ( $0,4 \mathrm{~cm}$ largura), enquanto a segunda possui cinco pares de folíolos obovados, nectário claviforme, presente apenas no primeiro par de folíolos e três estames longos. A espécie ocorre no Paraguai e no Brasil, nos estados de Minas Gerais, Rio de Janeiro, São Paulo, Paraná, Goiás e Mato Grosso (Irwin \& Barneby 1982). Ocupa ambientes de cerrado, sendo comumente encontrada em floresta de encosta, ao longo de estradas, pastagens, em lugares cultivados ou abandonados e em locais de altitude (Irwin \& Barneby 1982). Floresce de novembro a maio e frutifica de fevereiro a setembro. 
1.2.2 Senna pendula var. glabrata (Vogel) H.S. Irwin \& Barneby, Mem. New York Bot. Gard. 35: 382. 1982.

Fig. 2 i-1

Arbustos 1-3 m alt.; ramos jovens pubescentes. Estípulas 11-14 mm compr., lineares, pubescentes; pecíolo 2,2-2,8 cm compr., canaliculado, pubescente; raque 3,5$4,7 \mathrm{~cm}$ compr., canaliculada, pubescente; nectário foliar claviforme, entre o primeiro par de folíolos; folíolos 5 pares, 1,2-4×1-1,6 cm, obovados, ápice retuso, base levemente oblíqua, face adaxial glabra e abaxial pubescente. Inflorescências racemosas, terminais; pedúnculo 5-8 mm compr.; raque $2,5-3,7 \mathrm{~cm}$ compr., canaliculada, serícea a vilosa; brácteas 1,5-2,5 mm compr., lanceolada; cálice 5-10 $\mathrm{mm}$ compr., pubescente; corola $2-2,4 \mathrm{~cm}$ compr., zigomorfa; estames maiores 3 , filetes 22-30 mm compr., anteras ca. $10 \mathrm{~mm}$ compr., medianos 4, filetes ca. $2 \mathrm{~mm}$ compr., anteras 5-6 mm compr., estaminódios 3; ovário 17-21 $\mathrm{mm}$ compr., curvo, pubescente; estilete ca. 6 mm compr., curvo, glabro; estigma terminal, truncado, ciliado. Legume bacóide, 6-19 $\times 1-$ $1,5 \mathrm{~cm}$, subcilíndrico, glabro; 25-60 sementes, bisseriadas, $7 \times 4-5 \mathrm{~mm}$, oblongas, enegrecidas.

Material examinado: Fragmento da Eva, 28.IV.2006, fl., J. M. Fernandes 263 (VIC); idem, fl., J. M. Fernandes 270 (VIC); idem, 5.VIII.2006, fr., J. M. Fernandes 352 (VIC).

Senna pendula var. glabrata ocorre no Paraguai e no Brasil, nos estados de Minas Gerais, Mato Grosso, São Paulo, Bahia e Paraná (Irwin $\&$ Barneby 1982). Ocupa ambientes de cerrado, cerradão, mata ciliar entre 450-1.100 m, até os campos rupestres (Irwin \& Barneby 1982), incluindo áreas de pastagens, roças e beiras de estradas. Nos fragmentos, ocorre no subosque e entorno. Floresce de fevereiro a maio e frutifica de abril a agosto.

\section{Mimosoideae}

2.1 Mimosa L., Sp. Pl. 1: 516-523. 1753.

Árvores, arbustos, trepadeiras, subarbustos ou ervas; ramos inermes ou aculeados. Folhas bipinadas; estípulas presentes, na maioria das vezes persistentes; nectário foliar ausente; pinas 1-20 pares, opostas, primeiro par geralmente diferenciado em parafilídios. Inflorescências espiciformes ou capituliformes, axiais ou terminais, homomórficas ou heteromórficas; flores 3-6-mera; cálice gamossépalo, campanulado; corola gamopétala, campanulada, actinomorfa; androceu iso, diplostêmone ou polistêmone, filetes geralmente róseos ou purpúreos, livres ou unidos na base; gineceu unicarpelar; ovário pluriovulado. Fruto craspédio, deiscente ou indeiscente; semente não alada, pleurograma presente.

2.1.1 Mimosa diplotricha $\mathrm{C}$. Wright, Anales Acad. Ci. Med. Habana 5: 405. 1868.

Fig. 3 a-b

Subarbustos $30-40 \mathrm{~cm}$ alt.; ramos jovens esparsamente hirsutos, aculeados. Estípulas 3$4 \mathrm{~mm}$ compr., subuladas a lineares, persistentes; pecíolo 1,5-2,4 cm compr., quadrangular, hirsuto, aculeado; raque 1,4-1,8 cm compr., canaliculada, hirsuta; pinas 4-5 pares, foliólulos 13-17 pares por pina, $4-4,5 \times 1-1,5 \mathrm{~mm}$, oblongos, ápice agudo, base truncada, faces adaxial e abaxial glabrescentes. Inflorescências capituliformes, axilares, heteromórficas; flores masculinas ou hermafroditas; pedúnculo 0,3$0,8 \mathrm{~mm}$ compr.; raque $2-3 \mathrm{~mm}$ compr.; brácteas $0,8-1 \mathrm{~mm}$ compr., espatuladas; flores sésseis; cálice 5 sépalas, 0,5-0,8 mm compr., glabro; corola 4 pétalas, ca. $2,5 \mathrm{~mm}$ compr., glabra; estames 8, 4-6 $\mathrm{mm}$ compr., heterodínamos, róseos; ovário 0,6-1 mm compr., presença de tricomas glandulares na base; estilete 5-5,8 $\mathrm{mm}$ compr., levemente curvo; estigma terminal, infundibuliforme, glabro. Craspédio 1,3-1,8 $\times 0,4 \mathrm{~cm}, 3-5-$ articulados, híspido, estrigoso; sementes $3 \times 2$ $\mathrm{mm}$, oblongas, castanhas.

Material examinado: Fragmento da Eva, 25.II.2006, fl., J. M. Fernandes 170 (VIC).

Material adicional examinado: BRASIL. MINAS GERAIS: Belo Horizonte, Barreiro, Serra do Curral, 27.III.1955, fr., L.Roth s.n. (RB143085).

Mimosa diplotricha distingue-se de $M$. velloziana por apresentar de 4-5 pares de pinas, foliólulos de 13-17 pares por pina e flores com oito estames, enquanto que $M$. velloziana 


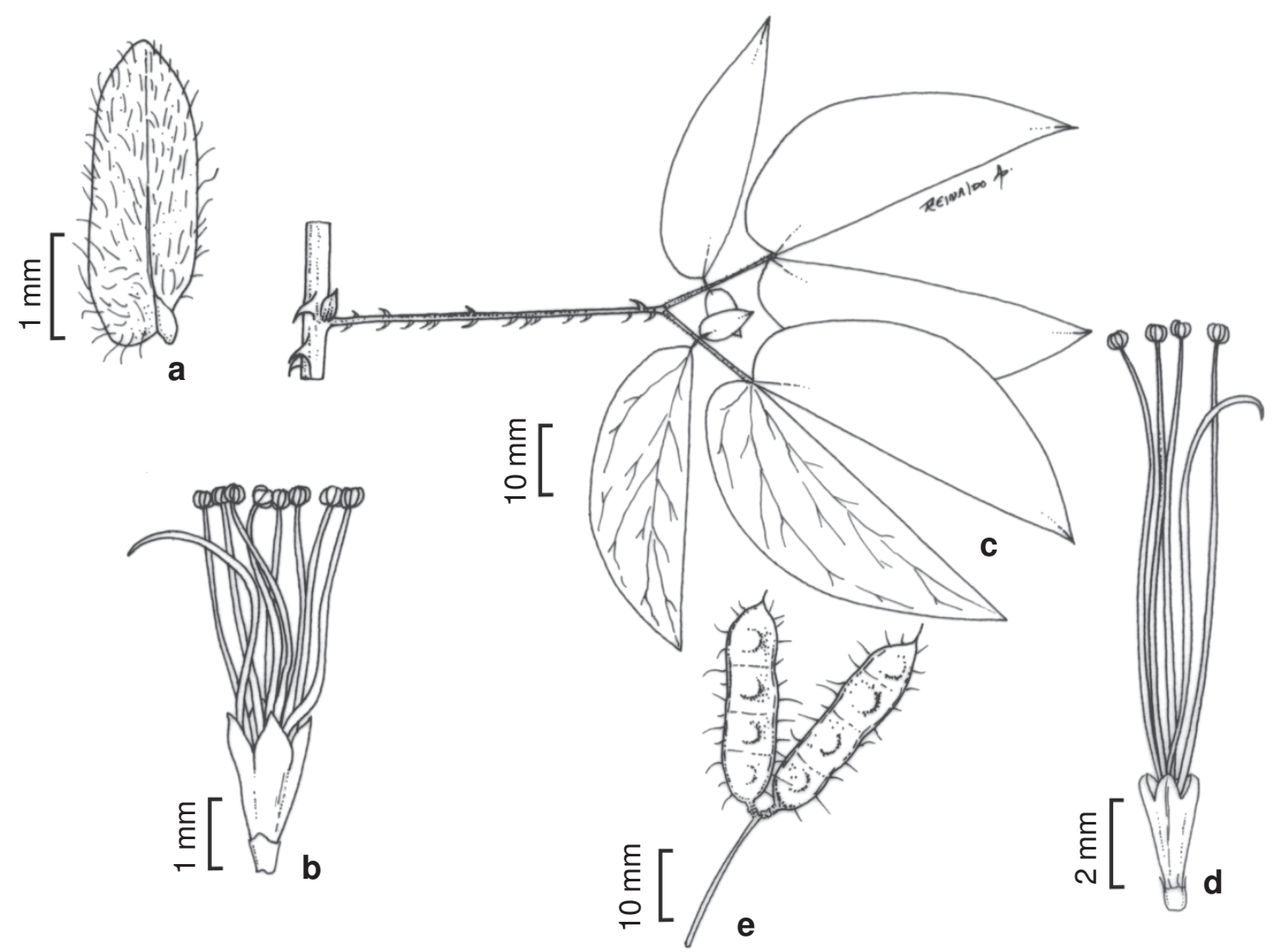

Figura 3 - a-b. Mimosa diplotricha - a. foliólulo; b. flor. c-e. M. velloziana - c. folha; d. flor; e. frutos (a-b Fernandes 170; c-e Fernandes 394).

apresenta exatamente um par de pina e 4 estames. Está distribuída do sul do México, Cuba, Porto Rico, Haiti, Equador, Brasil e, do Paraguai até a Argentina. No Brasil, ocorre na Bahia (Lewis 1987), Goiás, Minas Gerais e Santa Catarina (Barneby 1991). No Fragmento da Eva, ocorre em ambientes alterados e abertos com predominância de gramíneas. Floresce de fevereiro a abril, frutifica em março.

2.1.2 Mimosa velloziana Mart., Flora 22(1, Beibl.): 9. 1839.

Fig. 3 c-e

Arbustos 1-1,5 m alt.; ramos jovens glabrescentes, aculeados. Estípulas 2,5-3 mm compr., ovadas, glabrescentes, persistentes; pecíolo 1,6-6 cm compr., canaliculado, aculeado; raque $0,5-1 \mathrm{~cm}$ compr., canaliculada, tomentosa; pinas 1 par; foliólulos 2 pares por pina, 20-58 ×5-24 mm, elíptico-subfalcados, ápice agudo a acuminado, base oblíqua, margens ciliadas, face adaxial glabra e abaxial puberulenta. Inflorescências capituliformes, axilares, terminais; heteromórficas; pedúnculo 17-20 mm compr.; brácteas 2,3-3,5 mm compr., lanceolada, ciliada; raque ca. $3 \mathrm{~mm}$ compr.; cálice 5 sépalas, 0,3-0,4 mm compr.; corola 4 pétalas, 2,5-3 $\mathrm{mm}$ compr., serícea no ápice; estames 4 , ca. $10 \mathrm{~mm}$ compr., isodínamos, róseos com base avermelhada; ovário 5-6 mm compr., glabrescente; estilete $9-10 \mathrm{~mm}$ compr., glabro; estigma terminal, cilíndrico, glabro. Craspédio 3-4,5 × 1-1,3 cm, 3-5-articulado, aculeados; 3-5 sementes, 1,8-2 $\times 1-1,5 \mathrm{~mm}$, elípticas a obovadas, enegrecidas.

Material examinado: Fragmento da Lurdinha, 9.VI.2006, fr., J. M. Fernandes 289 (VIC).

Material adicional examinado: BRASIL. MINAS GERAIS: Araponga, comunidade São Joaquim (beira da estrada), 15.XI.2006, fl., J. M. Fernandes 394 (VIC); Reserva Florestal da Mata do Paraíso, 12.IX.2001, fr., F. C. P. Garcia e I. M. Corrêa 856 (VIC). 
Está distribuída no México, Panamá, Colômbia, Bolívia, Brasil, Paraguai e Venezuela. No Brasil, é citada para os estados do Pará, Goiás, Mato Grosso, Minas Gerais, Paraná e na região amazônica, ocupando áreas de altitude (Barneby 1991). No Fragmento da Lurdinha, ocorre apenas no entorno, em ambientes com predominância de gramíneas e trepadeiras. Floresce em novembro e frutifica de junho a setembro.

\section{Papilionoideae}

3.1 Aeschynomene elegans Schltdl. \& Cham., Linnaea 5: 583-584. 1830.

Fig. 4 a-b

Subarbustos 30-40 cm alt.; ramos jovens seríceos. Folhas paripinadas; estípulas 4-5 mm compr., lanceoladas, seríceas, persistentes; pecíolo 3-4 mm compr., canaliculado, seríceo; raque $1-2 \mathrm{~cm}$ compr., canaliculada, serícea; folíolos 8-12,0,6-1 $\times 0,3-0,5 \mathrm{~cm}$, oblongos, raro obovados, ápice arredondado, base aguda, faces adaxial e abaxial seríceas. Inflorescências pseudoracemosas, axilares; pedúnculo 1,5-2,3 cm compr.; raque 3-6 cm compr., canaliculada, serícea; brácteas ca. 1,6 mm compr., ovadas, pubescentes, ciliadas; flores pentâmeras; cálice gamossépalo, campanulado, 2-2,8 mm compr., seríceo; corola dialipétala, papilionácea, amarela, com guias de néctar, vináceo, vexilo 6,5-7 mm compr., alas 6-7 mm compr.; pétalas da carena 6-7 mm compr.; estames 10 , diadelfos $(5+5)$, 6-6,3 mm compr., anteras isomórficas; gineceu estipitado; estípite 1,3-1,5 mm compr.; ovário 3-3,5 mm compr., seríceo, pluriovulado; estilete 2-3 mm compr., reto, glabro; estigma terminal, infundibuliforme, glabro. Lomento 1-1,5×0,2 cm, 4-6-articulado, uncinado; 4-6 sementes, $2 \times$ 1,2 mm, reniformes, castanho-claras.

Material examinado: Fragmento da Lurdinha, 27.I.2006, fl. e fr., J. M. Fernandes et al. 139 (VIC); idem, 28.IV.2006, fl. e fr., J. M. Fernandes et al. 277 (VIC); Fragmento da Eva, 25.II.2006, fl. e fr., J. M. Fernandes et al. 173 (VIC).

Aeschynomene elegans é facilmente reconhecida na área por apresentar hábito subarbustivo, folhas paripinadas, 8-14 folíolos oblongos e frutos do tipo lomento. Está distribuída do México à Argentina (Brandão
1992). No Brasil, ocorre na Bahia, Pernambuco e nos estados das Regiões Sudeste e Sul, ocupando ambientes diversos, desde áreas muito secas até aquelas paludosas (Oliveira 2002). Ocorre apenas no entorno dos fragmentos em ambientes sombrios e úmidos. Floresce e frutifica o ano todo.

3.2 Camptosema bellum (Mart.) Benth., Fl. Bras. 15(1B): 156. 1862.

Fig. 4 c-d

Trepadeiras; ramos jovens esparso-seríceos. Folhas trifolioladas; estípulas 2-2,2 mm compr., lanceoladas, esparso-seríceas, caducas; pecíolo 2-4,2 cm compr., canaliculado, pubescente; raque 4-9 mm compr., canaliculada, esparso-serícea; folíolos laterais simétricos; folíolo terminal 2,65,3 × 1,7-2,5 cm compr., ovado-elíptico, ápice agudo, base arredondada, faces adaxial e abaxial glabrescentes. Inflorescências pseudoracemosas, axilares; pedúnculo 0,7-1,5 cm compr.; raque $2-3 \mathrm{~mm}$ compr., estriada, pubescente; flores não ressupinadas; brácteas 1-1,2 mm compr., amplo-ovadas, pubescentes; cálice gamossépalo, tubular, 27-28 mm compr., tetrâmero, avermelhado; corola dialipétala, ungüiculada, avermelhada, vexilo 4-5,4 cm compr., alas 3,7-4,9 cm compr., pétalas da carena 3,9-4,9 cm compr.; estames 10, diadelfos, 34$41 \mathrm{~mm}$ compr., anteras isomórficas; gineceu estipitado; estípite 10-15 mm compr.; ovário 10-12 mm compr., seríceo, pluriovulado; estilete 9-13 mm compr., reto; estigma terminal, truncado, glabro. Fruto não observado.

Material examinado: Fragmento da Eva, 25.II.2006, fl., J. M. Fernandes et al. 180 (VIC); idem, 28.IV.2006, fl., J. M. Fernandes et al. 266 (VIC).

Camptosema bellum é reconhecida na área estudada por apresentar hábito trepador, folíolos laterais simétricos, terminal ovadoelíptico, cálice tubular, tetrâmero e corola não ressupinada. É conhecida apenas em áreas serranas nos estados de Minas Gerais e Espírito Santo, em ambientes exclusivamente de subosque e de matas úmidas (Queiroz 1999). No Fragmento da Eva, ocorre em áreas úmidas do subosque. Floresce de fevereiro a abril, mas não houve a formação de frutos. 


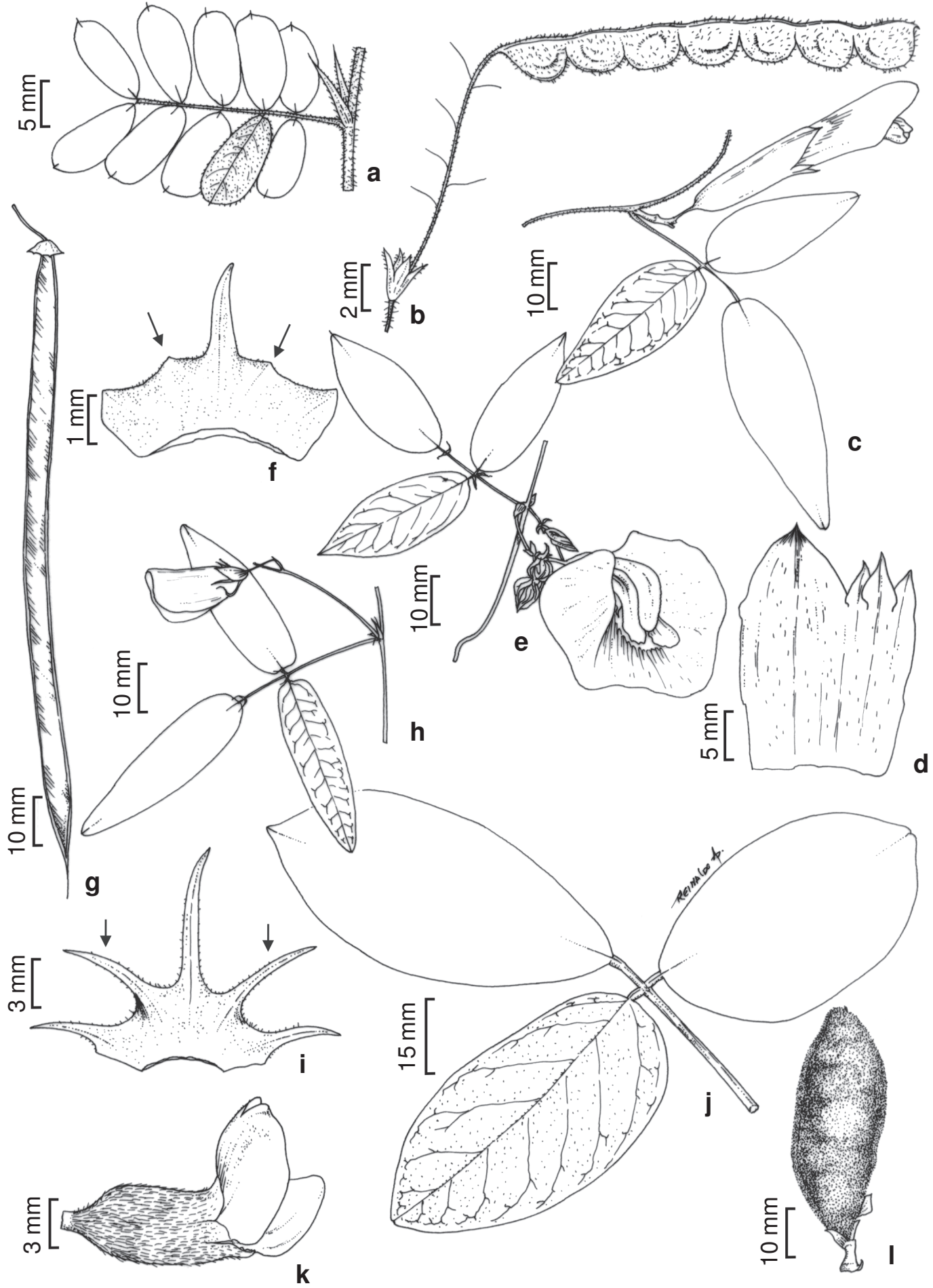

Figura 4 - a-b. Aeschynomene elegans - a. folha; b. fruto. c-d. Camptosema bellum - c. ramo com folha e flor; d. cálice. e-g. Centrosema arenarium - e. ramo com folha e flor; f. setas apontando lacínios laterais inferiores do cálice; g. fruto. h-i. Centrosema virginianum - h. ramo com folha e botão; i. setas apontando lacínios laterais inferiores do cálice. j-1. Cleobulia multiflora -j. folha; k. flor; 1. fruto. (a-d Fernandes 266; e-f Fernandes 268; g Fernandes 301; h-i Fernandes 238; j-k Fernandes 275; 1 Fernandes 392) 
3.3. Centrosema (DC.) Benth., Comm. Legum. Gen. 53-54. 1837.

Subarbustos, trepadeiras ou ervas. Folhas 1-3(-4-7) folioladas; estípulas e estipelas persistentes, raro caducas. Inflorescências racemosas, axilares, raramente terminais; flores pentâmeras, zigomorfas, ressupinadas; cálice gamossépalo, campanulado; corola gamopétala, ungüiculada, violácea, rosada, azulada ou alva, vexilo calcarado no dorso; estames 10, diadelfos (9+1), anteras isomórficas; gineceu séssil a subséssil, ovário pluriovulado. Fruto legume, deiscente, rostrado; semente cilíndrica ou oblonga.

\subsubsection{Centrosema arenarium Benth., Comm.} Legum. Gen. 55. 1837.

Fig. 4 e-g

Trepadeiras; ramos jovens seríceos. Folhas trifolioladas; estípulas 3-4 mm compr., triangulares, esparso-seríceas; pecíolo 1,1-3,3 cm compr., canaliculado, esparso-hirsuto; raque 0,7-1,5 cm compr., canaliculada, serícea; folíolos laterais simétricos; folíolo terminal 2,7-8 $\times 1-$ $3,5 \mathrm{~cm}$, ovado a ovado-lanceolado, ápice acuminado, base obtusa, faces adaxial e abaxial glabrescentes. Inflorescências racemosas, axilares ou terminais, 4-6 flora; pedúnculo 0,61,2 cm compr.; raque 4-7 mm compr., estriada, pubescente; brácteas 1-1,5 $\mathrm{mm}$ compr., triangulares; bractéolas 8-11 mm compr., ovadas, puberulentas; tubo do cálice ca. $4 \mathrm{~mm}$ compr., lacínios superiores 1-1,5 mm compr., lacínios laterais inferiores $1-1,5 \mathrm{~mm}$ compr., lacínio inferior mediano 5-6 mm compr.; corola púrpura, vexilo 2,8-3,5 cm compr., alas 2,3-2,5 cm compr., pétalas da carena $2,4-3 \mathrm{~cm}$ compr.; estames 25-27 mm compr.; ovário 13-15 mm compr., pubescente; estilete 5-7 mm compr., pubescente; estigma terminal, truncado, glabro. Legume 11-14×0,5 cm, plano-compresso, reto, glabrescente a pubescente; $10-15$ sementes, 5 $\times 3 \mathrm{~mm}$, oblongas, enegrecidas.

Material examinado: Fragmento da Eva, 1.V.2006, fl., J. M. Fernandes et al. 268 (VIC); idem, 28.VI.2006, fr., J. M. Fernandes et al. 301 (VIC).

Centrosema arenarium distingue-se de Centrosema virginianum, por apresentar folíolos ovados a ovado-lanceolados e lacínios laterais inferiores do cálice menores que o tubo, enquanto que a segunda espécie apresenta folíolos laterais e terminal lanceolados e lacínios laterais inferiores maiores que o tubo do cálice. Está distribuída do Ceará ao Paraná (BarbosaFevereiro 1977). Ocorre em locais de cerrado, litoral e serras úmidas, principalmente nos solos arenosos, terrenos abandonados ou cultivados (Barbosa-Fevereiro 1977). No Fragmento da Eva, ocorre no subosque e em áreas abertas do entorno. Floresce de abril a junho e frutifica de junho a agosto.

3.3.2 Centrosema virginianum (L.) Benth., Comm. Legum. Gen. 56. $1837 . \quad$ Fig. 4 h-i Trepadeiras; ramos jovens hirsutos. Folhas trifolioladas; estípulas 4-4,6 mm compr., triangulares a ovadas, pubescentes; pecíolo $2-$ $4 \mathrm{~cm}$ compr., canaliculado, pubescente; raque ca. $8 \mathrm{~mm}$ compr., canaliculada, pubescente; folíolos laterais simétricos, lanceolados; folíolo terminal 3,5-7,5×0,9-1,8 cm, lanceolado, ápice agudo, base emarginada, face adaxial puberulenta, face abaxial pubescente. Inflorescências racemosas, plurifloras, axilares; pedúnculo 2,5$3 \mathrm{~cm}$ compr.; brácteas 3,5-4 mm compr., lanceoladas, pubescentes; raque 3-7 $\mathrm{mm}$ compr., plana, pubescente; bractéolas 6-7 mm compr., ovadas a falcadas, pubescentes; tubo do cálice 4-6 mm compr., lacínios superiores ca. $3 \mathrm{~mm}$ compr., lacínios laterais inferiores 5-6 mm compr., lacínio inferior mediano 5-9 mm compr.; corola violácea, vexilo $2,2-2,5 \mathrm{~cm}$ compr., alas 1,6-1,8 cm compr., pétalas da carena 1,9-2 cm compr.; estames 20-24 mm compr.; ovário 12-13 mm compr., pubescente; estilete ca. $4 \mathrm{~mm}$ compr., pubescente; estigma terminal, truncado, glabro. Legume 8,5-9,5 $\times$ $0,3 \mathrm{~cm}$, plano compresso, levemente curvado, esparso-seríceo; 14-20 sementes, 3-3,8 $\times 2$ 2,2 mm, oblongas, marmoreadas.

Material examinado: Fragmento da Eva, 26.III.2006, fl., J. M. Fernandes et al. 238 (VIC).

Material adicional examinado: BRASIL. MINAS GERAIS: Ouro Preto, Parque Estadual do Itacolomi, 8.V.2004, fr., Dutra et al. 232 (VIC). 
Ocorre dos Estados Unidos à Argentina (Miotto 1987). No Brasil, está presente do Ceará ao Rio Grande do Sul (Barbosa-Fevereiro 1977). Ocorre em vegetação de restinga, cerrado, caatinga, praia, lugares úmidos ou secos, na sombra ou não, em solos argilosos ou arenosos (Barbosa-Fevereiro 1977). No Fragmento da Eva, ocorre em áreas úmidas do entorno. Floresce de fevereiro a abril e frutifica em maio.

3.4 Cleobulia multiflora Mart. ex Benth., Comm. Legum. Gen. 67. 1837 . Fig. 4 j-1

Trepadeiras; ramos jovens velutinos. Folhas trifolioladas; estípulas ca. 2 mm compr., triangulares, vilosas, persistentes; estipelas presentes; pecíolo 2,7-5 cm compr., subcilíndrico, viloso; raque $2-5 \mathrm{~mm}$ compr., subcilíndrica, vilosa; folíolos laterais assimétricos; folíolo terminal 6-10 $\times 3,8-4,5 \mathrm{~cm}$, elíptico, ápice obtuso, base arredondada, faces adaxial e abaxial vilosas. Inflorescências pseudo-racemosas, plurifloras, densifloras, axilares; pedúnculo 8-25 cm compr.; brácteas ca. 2,5 mm compr., ovadas, tomentosas; raque 5-14 cm compr., cilíndrica, tomentosa; bractéolas ca. $3 \mathrm{~mm}$ compr., ovadas, tomentosas; cálice gamossépalo, tubular, 4-5-mera, ca. $10 \mathrm{~mm}$ compr., ferrugíneo-viloso; corola dialipétala, papilionácea, 5-mera, lilás, vexilo 1,2-1,4 cm compr., alas 6-7 mm compr., pétalas da carena 1,1-1,2 cm compr.; estames diadelfo $(9+1)$, 10-12 mm compr., anteras isomórficas; ovário 6-8 mm compr., tomentoso, pluriovulado; estilete ca. $3 \mathrm{~mm}$ compr., curvo na base, glabro; estigma terminal, capitado. Legume 3-5×1,5$1,8 \mathrm{~cm}$, plano compresso, não constricto entre as sementes, ferrugíneo-viloso, sutura espessada; $1-3$ sementes, $9 \times 5-6 \mathrm{~mm}$, reniformes, castanho-marmoreadas.

Material examinado: Fragmento da Lurdinha, 28.IV.2006, fl., J. M. Fernandes 241 (VIC); idem, fl., J. M. Fernandes 275 (VIC); idem, 28.X.2006, fr., J. M. Fernandes 392 (VIC).

Cleobulia multiflora é caracterizada pelo hábito trepador, folíolos laterais assimétricos e terminais elípticos, inflorescência densiflora, cálice ferrugíneo-viloso externamente, corola lilás e legume reto. É uma espécie exclusivamente brasileira, ocorrendo nos estados da Bahia, Espírito Santo, Minas Gerais, Rio de Janeiro e Paraná (Maxwell 1977). Na área de estudo, a espécie foi encontrada em áreas de mata fechada, sob árvores, e em áreas de gramíneas no entorno dos fragmentos. Floresce de março a julho e frutifica de outubro a dezembro.

3.5 Crotalaria L., Sp. Pl. 2: 714-716. 1753.

Arbustos, subarbustos ou ervas. Folhas digitado-trifolioladas ou unifolioladas; estípulas e estipelas presentes ou caducas; alas internodais presentes ou ausentes. Inflorescências racemosas terminais, axilares ou opositifólias; flores pentâmeras; cálice bilabiado ou não bilabiado, gamossépalo, campanulado; corola dialipétala, papilionácea, amarela, às vezes com guias de néctar; estames 10, monadelfos, anteras heteromórficas, alternadas, 5 dorsifixas e 5 basifixas; ovário uniovulado a pluriovulado. Fruto legume, inflado, deiscente; semente reniforme a oblíquo-cordiforme com endosperma.

3.5.1 Crotalaria breviflora DC., Prodr. 2: 127. 1825 .

Fig. 5 a-b

Subarbustos 0,6-1,3 m alt.; ramos jovens seríceos a velutinos, alas internodais presentes, parte livre acuminada. Folhas unifolioladas; estípulas ca. 3 mm compr., ovadas, tomentosas, caducas; pecíolo 3-4 mm compr., canaliculado, velutino; folha unifoliolada, 4-9,5×1,6-3,5 cm, elíptica, ápice agudo, base aguda, faces adaxial e abaxial seríceas a velutinas. Pedúnculo 1,4$5 \mathrm{~cm}$ compr.; raque 5,5-12,5 cm compr., estriada, serícea; brácteas 7-10 mm compr., lanceoladas, vilosas; bractéolas 5-8 $\mathrm{mm}$ compr., lanceoladas, vilosas; cálice 6-16 mm compr., bilabiado, seríceo externamente; corola amarela com guias de néctar, vexilo 1,2-1,3 cm compr., alas 1,2-1,3 cm compr., pétalas da carena 1-1,2 cm compr.; estames ca. $10 \mathrm{~mm}$ compr.; ovário 5-6 mm compr., glabro; estilete 7-8 mm compr., geniculado, glabro; estigma terminal, funiliforme, glabro. Legume $3 \times 0,7-$ $1 \mathrm{~cm}$, glabro; 32 sementes, $2,3 \times 2,3 \mathrm{~mm}$, reniformes, castanhas. 
Material examinado: Fragmento da Eva, 27.I.2006, fl., J. M. Fernandes et al. 134 (VIC); Fragmento da Lurdinha, 26.III.2006, fr., J. M. Fernandes et al. 239 (VIC); idem, 16.XII.2006, fl., J. M. Fernandes 412(VIC).

Crotalaria breviflora distingue-se de Crotalaria incana pela presença de alas internodais no ramo, ocupando ou não todo o entrenó, com parte livre acuminada, unifoliolada, cálice bilabiado, corola com guias de néctar e fruto glabro, enquanto que a segunda espécie possui folhas trifolioladas, cálice não bilabiado, corola sem guias de néctar e fruto hirsuto. É restrita ao Brasil, ocorrendo principalmente na região central e sudeste do país, nos estados da Bahia, Goiás, Mato Grosso, Minas Gerais, Rio de Janeiro, São Paulo e Paraná (Filliettaz 2002). Segundo Flores (2004), ocorre em ambientes úmidos, próximos de cursos d'água em áreas de cerrado. Acrescenta Filliettaz (2002) que está presente em ambientes rochosos, campo rupestre, campo sujo, campos de altitude, borda de mata mesófila e de Mata Atlântica, mata ciliar, mata pluvial tropical, locais úmidos e paludosos. Ocorre em ambientes abertos no entorno dos fragmentos, principalmente em solos com bastante matéria orgânica. Floresce de dezembro a janeiro e frutifica de fevereiro a junho.

3.5.2 Crotalaria incana L., Sp. Pl. 2: 716. 1753.

Fig. 5 c-e

Subarbustos 0,8-1 m alt.; ramos jovens hirsutos ou seríceos, alas internodais ausentes. Folhas trifolioladas; estípulas 2-5 mm compr., lanceoladas a lineares, hirsutas; pecíolo 5,2$6,3 \mathrm{~cm}$ compr., cilíndrico, hirsuto; raque 2-3 mm compr., cilíndrica, hirsuta; folíolos laterais simétricos; folíolo terminal 3,1-4,1 × 1,8-2,4 $\mathrm{cm}$, obovado, ápice arredondado a obtuso, base cuneada, face adaxial glabra, face abaxial esparsamente hirsuta. Pedúnculo ca. $3,5 \mathrm{~cm}$ compr.; raque ca. $7 \mathrm{~cm}$ compr., cilíndrica, hirsuta; bráctea 7-8,5 mm compr., lanceolada, caduca, serícea; cálice 8-11 mm compr., não bilabiado, esparso-seríceo; corola amarela sem guias de néctar, vexilo ca. 1,9 cm compr., alas ca. 1,2 cm compr., pétalas da carena 1,2-1,3 cm compr.; estames 13-15 mm compr.; ovário 7-8 mm compr., seríceo a velutino; estilete 8-
$9 \mathrm{~mm}$ compr., geniculado na base, barbado; estigma terminal, truncado, glabro. Legume 3,5 $\times 1 \mathrm{~cm}$, hirsuto; 28 sementes, $2 \times 2 \mathrm{~mm}$, reniformes, castanhas.

Material examinado: Fragmento da Eva, 26.III.2006, fl., J. M. Fernandes et al. 231 (VIC).

Material adicional examinado: BRASIL. MINAS GERAIS: Araponga, comunidade dos Lanas (sistema agroflorestal do Sr. Ângelo), 12.VI.2006, fr., J. M. Fernandes 256 (VIC).

É uma espécie nativa dos trópicos do Novo Mundo, mas ocorre também na Ásia e África, sendo amplamente encontrada em todo o Brasil, principalmente em solos arenosos, margem de rios e capoeiras (Flores 2004). No entorno dos fragmentos, ocorre em áreas abertas sob dominância de gramíneas. Floresceu de março a maio e frutifica em junho.

3.6 Desmodium Desv., J. Bot. Agric. 1: 122, pl. 5 , f. 15.1813.

Arbustos, subarbustos ou ervas. Folhas 3 (5 ou 1) folioladas; estípulas e estipelas persistentes. Inflorescências pseudo-racemosas ou paniculadas, axilares ou terminais; flores pentâmeras, zigomorfas; cálice gamossépalo, campanulado; corola dialipétala, papilionácea, branca, violácea, purpúrea ou avermelhada; estames 10, diadelfos (9+1), anteras isomórficas; ovário pluriovulado. Fruto lomento, 2-8 articulado, deiscente ou indeiscente; sementes oblongas, obovadas ou reniformes.

3.6.1 Desmodium adscendens (Sw.) DC., Prodr. 2: 332. 1825.

Fig. 5 f-g

Subarbustos 20-30 cm alt.; ramos jovens vilosos. Folhas trifolioladas; estípulas 4-5 mm compr., cuneadas a triangulares, raramente lanceoladas, livres, glabras; pecíolo 5-8 $\mathrm{mm}$ compr., seríceo, canaliculado; raque 1-2 mm compr., canaliculada, vilosa, com tricomas uncinados; folíolos laterais simétricos, amploelípticos; folíolo terminal 0,6-1,9×0,7-1,2 cm, amplo-elíptico, ápice emarginado, base arredondada, face adaxial esparsamente serícea, face abaxial serícea. Inflorescências pseudoracemosas, terminais; pedúnculo $1-2,5 \mathrm{~cm}$ 


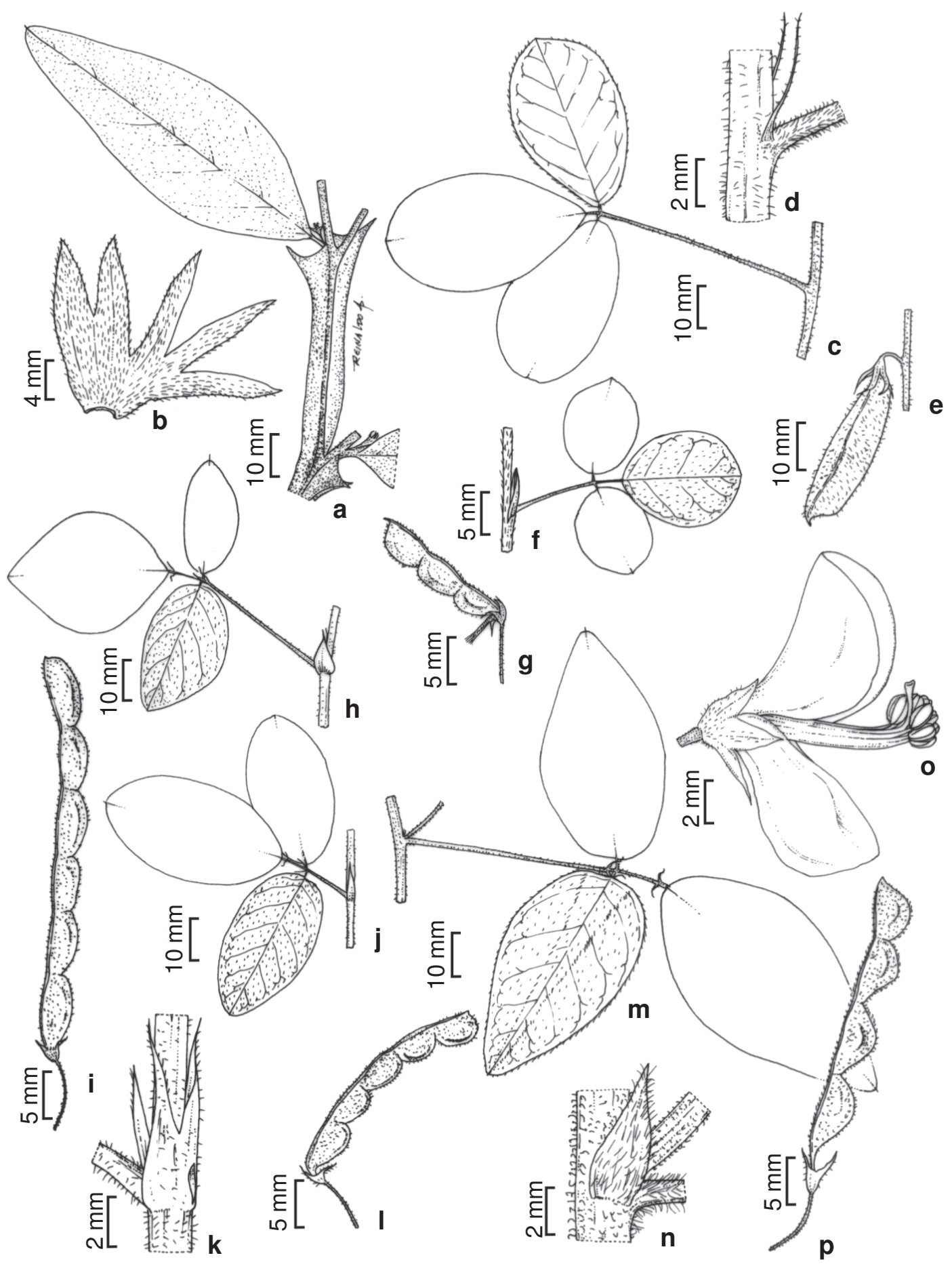

Figura 5 - a-b. Crotalaria breviflora - a. ramo com alas e folha; b. cálice; c-e. C. incana - c. folha; d. estípulas; e. fruto; f-g. Desmodium adscendens - f. folha; g. fruto; h-i. D. affine - h. folha; i. fruto; j-1. D. incanum - j. folha; k. estípulas; 1. fruto; m-p. D. uncinatum - m. folha; n. estípula; o. flor; p. fruto. (a Fernandes 239; b Fernandes 134; c-e Fernandes 256; f Fernandes 138; g Fernandes 419; h-i Fernandes 414; j-1 Fernandes 407; m-n Fernandes 262; o Fernandes 276; p Fernandes 262) 
compr.; raque 4,5-8,5 cm compr., canaliculada, pubescente; brácteas 3,4-4,2 mm compr., lanceoladas, seríceas; bractéolas caducas; cálice 3-3,3 mm compr., pubescente externamente; corola rosada, vexilo 6-6,5 mm compr., alas 5-6 mm compr., pétalas da carena 6-6,1 mm compr.; estames 5-6 mm compr.; ovário 3,5-3,7 mm compr., seríceo; estilete ca. 2,5 mm compr., curvo, glabro; estigma terminal, capitado, glabro. Lomento $0,7-2,1 \times 0,3 \mathrm{~cm}$, 1-3 articulado, semi-elípticos, com tricomas uncinados; 1-3 sementes, $4 \times 2 \mathrm{~mm}$, obovadas, avermelhadas.

Material examinado: Fragmento da Lurdinha, 27.I.2006, fl., J. M. Fernandes et al. 138 (VIC); idem, 14.II.2006, fr., J. M. Fernandes et al. 190 (VIC).

Desmodium adscendens é facilmente reconhecida dentre as espécies de Desmodium que ocorrem na área de estudo, por apresentar folíolos terminais amplo-elípticos com ápice emarginado. Esta espécie é encontrada na Ásia, África e América, desde o México até a Argentina (Vanni 2001), incluindo todo o Brasil (Azevedo 1981). Cresce em solos arenosos ou argilosos, secos ou úmidos, ensolarados ou sombrios; ocorre na caatinga, campo rupestre, cerrado, restinga, em áreas de pastagens, brejos, matas, dunas, margens de rios e estradas, capoeiras e carrasqueiros (Azevedo 1981). Ocorre em áreas abertas no entorno dos fragmentos. Floresce de dezembro a abril e frutifica de fevereiro a julho.

3.6.2 Desmodium affine Schltdl., Linnaea 12: 312-313. 1838.

Fig. 5 h-i

Subarbustos 30-40 cm alt.; ramos jovens com tricomas uncinados, hirsutos. Folhas trifolioladas; estípulas 5-10 mm compr., lanceoladas a ovadas, livres, glabrescentes; pecíolo 2,5-3,2 cm compr., estriado, uncinado, seríceo; raque 5-8 mm compr., estriada, com tricomas uncinados; folíolos laterais assimétricos; folíolo terminal 3,6-5,4 × 1,8-3,2 $\mathrm{cm}$, ovado, ápice agudo, base arredondada a truncada, face adaxial serícea, face abaxial com tricomas uncinados. Inflorescências pseudo-racemosas, terminais; pedúnculo ca. 8 cm compr.; raque 3,5-10,7 cm compr., estriada, serícea, uncinada; brácteas 3,5-5 mm compr., ovadas, ciliadas, caducas; cálice 3,8-4 mm compr., seríceo; corola rosada, vexilo 5-6 mm compr., alas 5,5-6 mm compr., pétalas da carena 5,2-6 mm compr.; estames ca. $4 \mathrm{~mm}$ compr.; ovário ca. 3,5 mm compr., seríceo; estilete ca. 1,5 mm compr., levemente curvado, glabro; estigma terminal, capitado, glabro. Lomento 2,5-4 × 0,3 cm, 3-7 articulado, semielípticos, com tricomas uncinados; 3-7 sementes, $3,5 \times 2,5 \mathrm{~mm}$, reniformes, cinza-claras. Material examinado: Fragmento da Eva, 13.XII.2005, fr., J. M. Fernandes et al. 108 (VIC); Fragmento da Lurdinha, 16.XII.2006, fl. e fr., J. M. Fernandes 414 (VIC).

Desmodium affine distingue-se de $D$. incanum por apresentar folíolos laterais assimétricos, folíolos terminais ovados e pelos artículos semi-elípticos, enquanto que a segunda espécie apresenta folíolos laterais simétricos e terminais elípticos, estípulas lanceoladas e soldadas. É uma espécie de distribuição neotropical, ocorrendo desde o México até a Argentina (Vanni 2001). Ocorre em cerrado, campo rupestre, principalmente em mata, preferindo lugares sombrios e úmidos, sendo encontrada em campos, capoeira e pastagem (Azevedo 1981). Nos fragmentos, ocorre em áreas abertas do entorno. Floresce de outubro a fevereiro e frutifica de dezembro a abril.

3.6.3 Desmodium incanum DC., Prodr. 2: 332. 1825 .

Fig. 5 j-1

Subarbustos 30-40 cm alt.; ramos jovens com tricomas uncinados. Folhas trifolioladas; estípulas 5-8 $\mathrm{mm}$ compr., lanceoladas, soldadas, esparso-seríceas; pecíolo 0,7-1,3 cm compr., canaliculado, hirsuto a puberulento; raque 3-4 mm compr., canaliculada, hirsuta, com tricomas uncinados; folíolos laterais simétricos, elípticos; folíolo terminal 2,1-3,3× 1,1-2,3 cm, elíptico, ápice obtuso, base arredondada. Inflorescências pseudoracemosas, terminais; pedúnculo $5-7 \mathrm{~cm}$ compr.; raque 6-9 cm compr., estriada, com tricomas uncinados; brácteas 3-3,5 mm compr., ovadas a lanceoladas, glabrescentes; cálice ca. $3 \mathrm{~mm}$ compr., esparso-seríceo; corola rosada 
a avermelhada, vexilo ca. 7,5 mm compr., alas ca. 6,5 mm compr., pétalas da carena ca. 6 mm compr.; estames 5-6 mm compr.; ovário ca. $4 \mathrm{~mm}$ compr., seríceo; estilete ca. $1,5 \mathrm{~mm}$ compr., levemente curvado, glabro; estigma terminal, capitado, glabro. Lomento $1-2 \times 0,3$ cm, 2-6 articulado, oblongos, com tricomas uncinados; 2-6 sementes, 2-2,2×1,1-1,5 mm, reniformes, esverdeadas.

Material examinado: Fragmento da Lurdinha, 28.X.2006, fl. e fr., J. M. Fernandes 393 (VIC); idem, 16.XII.2006, fl. e fr., J. M. Fernandes 407 (VIC).

No Brasil, ocorre em todos os estados; em ambiente de cerrado, floresta amazônica e restinga, em áreas de capoeira, várzea, duna, beira de estrada, pastagem e em áreas cultivadas (Azevedo 1981). Nos fragmentos, ocorre no entorno em locais abertos ensolarados e sombreados. Floresce e frutifica em dezembro.

\subsubsection{Desmodium uncinatum (Jacq.) DC.,} Prodr. 2: 331. 1825. Fig. $5 \mathrm{~m}-\mathrm{p}$

Subarbustos 0,6-1 m alt.; ramos jovens com tricomas uncinados. Folhas trifolioladas; estípulas 5-8 mm compr., triangulares, tricomas uncinados; pecíolo 2,2-3,5 cm compr., estriado, hirsuto, uncinado; raque $0,5-1,1 \mathrm{~cm}$ compr., canaliculada, hirsuta; folíolos laterais simétricos; folíolo terminal 3,5-5×1,7-2,8 cm, ovado, ápice agudo, base arredondada, faces adaxial e abaxial velutínas. Inflorescências paniculadas, terminais; pedúnculo $1,5-8,2 \mathrm{~cm}$ compr.; raque 7,4-15,5 cm compr., estriada com tricomas uncinados; brácteas 4-6 mm compr., lanceoladas a ovadas; cálice 4-5 mm compr., esparso-seríceo; corola arroxeada, vexilo ca. $1 \mathrm{~cm}$ compr., alas $1-1,2 \mathrm{~cm}$ compr., pétalas da carena 1-1,2 cm compr.; estames 9-10 mm compr.; ovário 6-7 mm compr., seríceo; estilete ca. $3 \mathrm{~mm}$ compr., curvo na base, glabro; estigma terminal, capitado, glabro. Lomento $1,8-3,2 \times 0,4 \mathrm{~cm}, 1-4$ articulado, triangulares, com tricomas uncinados; $1-4$ sementes, $2 \times 1 \mathrm{~mm}$, oblongas, esverdeadas.

Material examinado: Fragmento da Lurdinha, 28.IV.2006, fl., J. M. Fernandes et al. 276 (VIC). Material adicional examinado: BRASIL. MINAS GERAIS: Araponga, comunidade Lanas (sistema agroflorestal do Sr. Ângelo) 12.IV.2006, fr., J. M. Fernandes 262 (VIC).

Desmodium uncinatum diferencia-se das outras espécies de Desmodium ocorrentes na área de estudo, por apresentar artículos triangulares. Está distribuída desde a América Central até Argentina (Vanni 2001). No Brasil, ocorre da Bahia até o Rio Grande do Sul (Azevedo 1981). Habita cerrado, restinga, campo rupestre, em áreas de mata, pastagem, capoeira, em lugares úmidos como margem de represas ou córregos, tornando-se uma espécie ruderal e invasora (Azevedo 1981). Floresce e frutifica em abril.

3.7 Indigofera suffruticosa Mill., Gard. Dict. (ed. 8) n. 2. 1768.

Fig. 6 a-c

Arbustos ca. $1 \mathrm{~m}$ alt.; ramos jovens estrigosos com tricomas malpighiáceos adpressos. Folhas imparipinadas; estípulas 2,5-4 mm compr., lineares, persistentes; pecíolo 1,8-2,4 cm compr., achatado, estrigoso; raque 6-7,5 cm compr., achatada, estrigosa; folíolos 13-17, 1,5-2,7 ×0,4-0,9 cm, elípticos, ápice agudo, base obtusa, face adaxial glabra, face abaxial estrigosa esbranquiçada. Inflorescências racemosas, axilares; pedúnculo 2-3 mm compr.; raque 7-11,2 cm compr., estriada, estrigosa; brácteas 1,5-1,7 mm compr., subuladas, caducas; flores pentâmeras; cálice gamossépalo, campanulado, 1-1,2 mm compr., puberulento; corola dialipétala, papilionácea, salmão, vexilo 4-4,2 mm compr., alas 3,8-4 mm compr., pétalas da carena 4 4,5 mm compr.; estames $10(9+1)$, diadelfos, ca. $4 \mathrm{~mm}$ compr., anteras isomórficas, apiculadas; ovário ca. 2,5 mm compr., linear, seríceo; estilete ca. $1 \mathrm{~mm}$ compr., curvado, glabro; estigma terminal, capitado, ciliado. Legume 1,6-2,3 × 0,2-0,3 cm, curvado, esparsamente estrigoso; 4-6 sementes, 1,8$2,4 \times 1,2 \mathrm{~mm}$, cuboidais, enegrecidas.

Material examinado: Fragmento da Eva, 25.II.2006, fl. e fr., J. M. Fernandes et al. 174 (VIC).

Indigofera suffruticosa é reconhecida por apresentar tricomas malpighiáceos, inflorescência menor que o comprimento da folha, fruto fortemente curvado e sementes 
cuboidais. Está distribuída nos trópicos e subtrópicos. No Brasil, ocorre em todos os estados (Rodas 1991). Encontrada em restinga, cerrado, caatinga, em áreas de campos, beira de estrada, borda de mato, capoeira, pastagens, lugares úmidos, praias e em áreas de cultivo (Eisinger 1987; Rodas 1991). Ocorre em áreas abertas no entorno do Fragmento da Eva. Floresce de novembro a abril e frutifica de fevereiro a junho.

3.8 Rhynchosia phaseoloides (Sw.) DC., Prodr. 2: 385. 1825. Fig. $6 \mathrm{~d}-\mathrm{h}$

Trepadeiras; ramos jovens velutinos. Folhas trifolioladas, com tricomas glandulares; estípulas 3-5 mm compr., lanceoladas, pubescentes, caducas; pecíolo 2,5-6,8 cm compr., sulcado, viloso; raque 1,7-2,5 cm compr., sulcada, vilosa; folíolos laterais assimétricos; folíolo terminal 4,1-14,5 ×2,2-9,7 cm, ovado, ápice acuminado, base obtusa a subtruncada, face adaxial esparso-velutina, face abaxial denso-velutina. Inflorescências racemosas, terminais; pedúnculo 2,5-6 cm compr.; raque 8-20,1 cm compr., estriada, velutina; brácteas caducas; flores pentâmeras; cálice campanulado, gamossépalo, 5-5,1 mm compr., pubescente; corola dialipétala, papilionácea, amarela com guias de néctar castanho avermelhados, vexilo 0,9-1 cm compr., alas ca. 9 mm compr., pétalas da carena ca. $1 \mathrm{~cm}$ compr.; estames diadelfos (9+1), 8-9 mm compr., anteras isomórficas; ovário 3-4 mm compr., subséssil, seríceo, biovulado; estilete ca. $5 \mathrm{~mm}$ compr., curvo no ápice, esparso-seríceo; estigma terminal, capitado, glabro. Legume 1,5-2,4 ×0,9 cm, plano compresso, constrito entre as sementes, deiscente, tomentoso; 2 sementes, $4 \times 2,5-3 \mathrm{~mm}$, orbiculares, hilo vermelho.

Material examinado: Fragmento da Eva, 14.II.2006, fl. e fr., J. M. Fernandes et al. 182 (VIC).

Rhynchosia phaseoloides caracterizase pelos folíolos laterais assimétricos, folíolo terminal ovado, flores com a corola amarela e guias de néctar vináceos sobre o vexilo e frutos tomentosos com sementes bicolores, pretas e vermelhas. Ocorre do norte ao nordeste da Argentina até a América Central. No Brasil, foi coletada nos estados do Rio Grande do Sul, Santa Catarina, Paraná, Mato Grosso do Sul, São Paulo, Goiás, Maranhão, Mato Grosso (Miotto 1988) e Minas Gerais (Bortoluzzi et al. 2003). Habita locais de capoeiras, beiras de matas secundárias, mata ciliar e em floresta de araucária (Miotto 1988). Ocorre em áreas úmidas no entorno dos fragmentos. Floresce de dezembro a março e frutifica de fevereiro a maio.

3.9 Stylosanthes guianensis (Aubl.) Sw. var. guianensis, Kongl. Vetensk. Acad. Nya Handl. 10: 301. 1789.

Fig. $6 \mathrm{i}-\mathrm{j}$

Subarbustos $40-50 \mathrm{~cm}$ alt.; ramos jovens hirsutos, viscosos. Folhas trifolioladas; estípulas 10-12 mm compr., amplexicaules, lanceoladas, hirsutas; estipelas ausentes; pecíolo 3-7 $\mathrm{mm}$ compr., canaliculado, pubescente; raque ca. 1 mm compr., estriada, canaliculada; folíolos laterais simétricos, elípticos; folíolo terminal 1,22,6 $\times 0,3-0,7 \mathrm{~cm}$, elíptico a lanceolado, ápice agudo, base aguda, faces adaxial e abaxial pubescentes. Inflorescências espiciformes, terminais; pedúnculo 1,8-5 cm compr.; brácteas 6-9 mm compr., lanceoladas, externamente com cerdas; bractéolas 3,5-5 mm compr., presença de cerdas na margem do ápice; flores pentâmeras; cálice gamossépalo, tubular, 7-8,3 mm compr., glabro; corola dialipétala, papilionácea, amarelada, vexilo 55,2 mm compr., alas 4,2-4,8 mm compr., pétalas da carena ca. $4 \mathrm{~mm}$ compr.; estames 10, monadelfos, ca. $4 \mathrm{~mm}$ compr., anteras heteromórficas; ovário ca. $1 \mathrm{~mm}$ compr., glabro, biovulado; estilete 6,3-7,2 mm compr., curvado, glabro; estigma terminal, cilíndrico, glabro. Lomento $0,2-0,25 \times 0,15-0,2 \mathrm{~cm}, 1$ articulado, indeiscente, glabro; 1 semente, 1,6$2 \times 1 \mathrm{~mm}$, reniforme, enegrecida.

Material examinado: Fragmento da Eva, 28.IV.2006, fl., J. M. Fernandes et al. 269 (VIC); idem, 12.IX.2006, fr., J. M. Fernandes et al. 380 (VIC).

É reconhecida na área estudada por apresentar estípula amplexicaule, caule pilosocerdoso e viscoso, podendo chegar até $2 \mathrm{~mm}$ de comprimento, fruto com apenas um artículo. Essa variedade ocorre desde o México até 


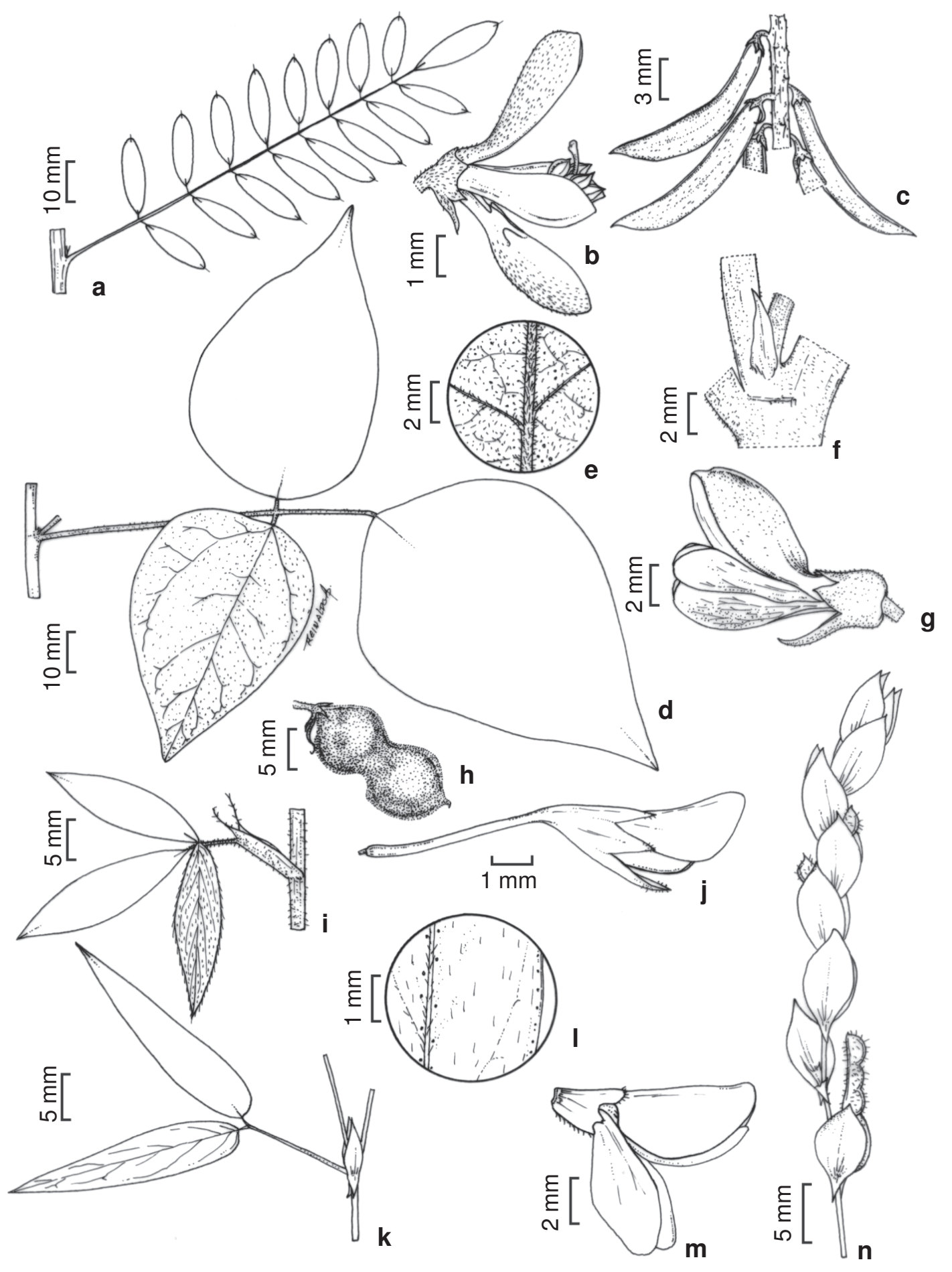

Figura 6 - a-c. Indigofera suffruticosa - a. folha; b. flor; c. frutos; d-h. Rhynchosia phaseoloides - d. folha; e. indumento da face abaxial do folíolo; f. estípula; g. flor; h. fruto; i-j. Stylosanthes guianensis var. vulgaris - i. folha com estípulas amplexicaule; j. flor; k-m. Zornia gemella - k. folha; 1 indumento da face abaxial do folíolo; m. flor; n. raque com brácteas e frutos (a-c Fernandes 174; d-h Fernandes 182; i-j Fernandes 269; k-m Fernandes 233). 
o Paraguai. No Brasil é encontrada nos estados do Pará, Bahia, Paraíba, Minas Gerais, São Paulo, Mato Grosso, Paraná e Rio de Janeiro (Mannetje 1977). No Fragmento da Eva, ocorrem em áreas abertas. Floresce de novembro a maio e foi coletada com fruto em setembro.

3.10 Zornia gemella Vogel, Linnaea 12: 6162. 1838.

Fig. $6 \mathrm{k}-\mathrm{n}$

Subarbustos 20-30 cm alt.; ramos jovens glabros. Folhas bifolioladas; estípulas 3-5 mm compr., peltadas, glabras; pecíolo $1-1,5 \mathrm{~cm}$ compr., cilíndrico, glabro; folíolos 1-2,5×0,4$0,7 \mathrm{~cm}$, elípticos a lanceolados, ápice acuminado, base obtusa, face adaxial glabra e abaxial esparso-serícea. Inflorescências espiciformes, terminais; raque 4-8 cm compr., estriada, esparso-serícea; brácteas $8-10 \mathrm{~mm}$ compr., oblongo-lanceoladas, glabras, ciliadas; flores pentâmeras; cálice gamossépalo, campanulado, 2-3 mm compr., glabro, ciliado; corola dialipétala, papilionácea, amarela, vexilo 7-8 mm compr., alas 5-6,5 mm compr., pétalas da carena 7-7,5 mm compr.; estames 10 , monadelfos, 6-7 $\mathrm{mm}$ comp., anteras heteromórficas; ovário 2,5-3 mm compr., seríceo, aculeado; estilete ca. 4,5 mm compr., reto, glabro; estigma terminal, capitado, glabro. Lomento $0,8-0,9 \times 0,2 \mathrm{~cm}, 3-6$-articulado, artículos com cerdas; $3-6$ sementes, $1 \times 1 \mathrm{~mm}$, quadrangulares, esverdeadas.

Material examinado: Fragmento da Eva, 25.II.2006, fr., J. M. Fernandes et al. 171 (VIC); idem, 26.III.2006, fr., J. M. Fernandes et al. 233 (VIC).

Zornia gemella é reconhecida pelas folhas bifolioladas, estípulas com base peltada, folíolos elípticos a lanceolados, inflorescências espiciformes com brácteas oblongolanceoladas e fruto lomento. Ocorre dos Estados Unidos até a Argentina. No Brasil está distribuída nos estados de São Paulo, Minas Gerais, Rio de Janeiro e Rio Grande do Sul (Mohlenbrock 1961). Nos fragmentos, ocorre em locais abertos e sombreados do entorno. Floresce de dezembro a abril e frutifica de janeiro a julho.

\section{Agradecimentos}

Ao CNPq, pela bolsa de mestrado concedida ao primeiro autor; ao Centro de Tecnologias Alternativas da Zona da Mata Mineira, FAPEMIG e ao Programa de PósGraduação em Botânica da UFV, pelo apoio técnico e financeiro; ao ilustrador botânico Reinaldo Pinto; ao Sr. Ângelo da Guarda Costa, representando os proprietários dos fragmentos florestais; aos colegas de campo Lívia C. de Siqueira, Carolina B. M. Pellucci e Rafael Polizel; aos revisores que deram contribuições valiosas ao trabalho.

\section{REFERÊNCIAS BIBLIOGRÁFICAS}

Azevedo, A. M. G. 1981. O gênero Desmodium Desv. no Brasil - considerações taxonômicas. Dissertação de Mestrado. Universidade Estadual de Campinas, Campinas, 315p.

Barbosa-Fevereiro, V. P. 1977. Centrosema (A. P. De Candolle) Bentham do Brasil Leguminosae - Faboideae. Rodriguésia 42(1): 159-219.

Barneby, R. C. 1991. Sensitivae Censitae. A description of the genus Mimosa Linnaeus (Mimosaceae) in the New World. Memoirs of New York Botanical Garden 65: 1-835.

Barroso, G. M.; Morim, M. P.; Peixoto, A. L. \& Ichasso, C. L. F. 1999. Frutos e sementes: morfologia aplicada à sistemática de dicotiledôneas. Imprensa Universitária, Viçosa, 443p.

Bortoluzzi, R. L. C. 2004. A subfamília Caesalpinioideae (Leguminosae) no Estado de Santa Catarina, Brasil. Tese de Doutorado. Universidade Federal do Rio Grande do Sul, Porto Alegre, 319p.

Bortoluzzi, R. L. C.; Garcia, F. C. P.; CarvalhoOkano, R. M. \& Tozzi, A. M. G. A. 2003. Leguminosae-Papilionoideae no Parque Estadual do Rio Doce, Minas Gerais, Brasil. I: trepadeiras e subarbustos. Iheringia, Série Botânica 58: 25-60.

Bortoluzzi, R. L. C.; Carvalho-Okano, R. M.; Garcia, F. C. P. \& Tozzi, A. M. G. A. 
2004. Leguminosae, Papilionoideae no Parque Estadual do Rio Doce, Minas Gerais, Brasil II: árvores e arbustos escandentes. Acta Botanica Brasilica 18(1): 49-71.

Brandão, M. 1992. Gênero Aeschynomene L.: espécies mineiras e sua distribuição no país. Daphne 2(3): 27-46.

Chappill, J. A. 1995. Cladistic analysis of the Leguminosae: the development of an explicit phylogenetic hypothesis. In: Crisp, M. \& Doyle, J. J. (eds.). Advances in Legume Systematic 7: Phylogeny. Royal Botanic Gardens, Kew. Pp. 1-9.

Eisinger, S. M. 1987. O gênero Indigofera L. (Leguminosae - Papilionoideae Indigofereae) no Rio Grande do Sul-Brasil. Acta Botanica Brasilica 1(2): 123-140.

ENGEVIX. 1995. Caracterização do meio físico da área autorizada para criação do Parque Estadual da Serra do Brigadeiro. Instituto Estadual de Floresta, Bird/PróFloresta/ SEPLA, 34p.

Fidalgo, O. \& Bononi, V. L. R. 1989. Técnicas de coleta, preservação e herborização do material botânico. Instituto de Botânica, São Paulo, 61p.

Filardi, F. L. R.; Garcia, F. C. P. \& CarvalhoOkano, R. M. 2007. Espécies lenhosas de Papilionoideae (Leguminosae) na Estação Ambiental de Volta Grande, Minas Gerais, Brasil. Rodriguésia 58(2): 363-378.

Filliettaz, A. M. 2002. Estudos taxonômicos de espécies de Crotalaria sect. Calycinae Wight \& Arn. (Leguminosae Papilionoideae - Crotalarieae) no Brasil. Dissertação de Mestrado. Universidade Estadual de Campinas, Campinas, 155p.

Flores, A. S. 2004. Taxonomia, números cromossômicos e química de espécies de Crotalaria L. (Leguminosae-Papilionoideae) no Brasil. Tese de Doutorado. Universidade Estadual de Campinas, Campinas, 213p.

Golfari, L. 1975. Zoneamento ecológico do estado de Minas Gerais para reflorestamento. Série técnica, 3. CPFRC, Belo Horizonte/ MG, 181p.
Guedes-Bruni, R. R.; Morim, M. P.; Lima, H. C. \& Sylvestre, L. S. 2002. Inventário florístico. In: Sylvestre, L. S. \& Rosa, M. M. T. Manual metodológico para estudos botânicos na Mata Atlântica. Rio de Janeiro: Seropédica. Pp. 24-49.

Irwin, H. S. \& Barneby, R. C. 1982. The American Cassinae, a synoptical revision of Leguminosae, Tribe Cassieae, subtribe Cassinae in the New World. Memoires of the New York Botanical Garden 35(12): 1-918.

Lewis, G. 1987. Legumes of Bahia. Kew: Royal Botanic Gardens, 369p.

Lewis, G.; Schrine, B.; Mackinder, B. \& Lock, M. 2005. Legumes of the world. Royal Botanic Gardens, Kew, 577p.

Lima, H. C. 2000. Leguminosas arbóreas da Mata Atlântica - uma análise da riqueza, padrões de distribuição geográfica e similaridades florísticas em remanescentes florestais do estado do Rio de Janeiro. Tese de Doutorado. Universidade Federal do Rio de Janeiro, Rio de Janeiro, 122p.

Lima, L. C. P.; Garcia, F. C. P. \& Sartori, A. L. B. 2007. Leguminosae nas florestas estacionais do Parque Estadual do Itacolomi, Minas Gerais, Brasil: ervas, arbustos, subarbustos, lianas e trepadeiras. Rodriguésia 58(2): 331-358.

Mannetje, L. T. 1977. A revision of varieties of Stylosanthes guianensis (Aubl.) Sw. Australian Journal of Botany 25: 347-362.

Maxwell, R. H. 1977. A resume of the genus Cleobulia (Leguminosae) and its relation to the genus Dioclea. Phytologia 38: 51-65.

Mendonça-Filho, C. V. 1996. Braúna, angico, jacarandá e outras leguminosas de Mata Atlântica: Estação Biológica de Caratinga, Minas Gerais. Fundação Botânica Margaret Mee; Fundação Biodiversitas, Belo Horizonte, 100p.

Miotto, S. T. S. 1987. Os gêneros Centrosema (DC.) Benth. e Clitoria L. (Leguminosae, Faboideae) no Rio Grande do Sul. Iheringia, Série Botânica 36: 15-39. 
. 1988. Flora ilustrada do Rio Grande do Sul, fasc. 19. Leguminosae-Faboideae, Tribo Phaseoleae, Subtribo Cajaninae. Boletim do Instituto de Biociências 43: 1-88.

Mohlenbrock, R. 1961. A monograph of the Leguminous genus Zornia. Webbia 16: 1-144.

Müller, S. C. \& Waechter, J. L. 2001. Estrutura sinusial dos componentes herbáceo e arbustivo de uma floresta costeira subtropical. Revista Brasileira de Botânica 24(4): 395-406.

Oliveira-Filho, A. T. 2006. Catálogo das árvores nativas de Minas Gerais: mapeamento e inventário da flora nativa e dos reflorestamentos de Minas Gerais. UFLA, Lavras, 423p.

Oliveira, M. L. A. A. de. 2002. Sinopse taxônomica do gênero Aeschynomene L. (Leguminosae- Faboideae) no Rio Grande do Sul, Brasil. Iheringia, Série Botânica 57(2): 279-301.

Queiroz, L. P. 1999. Sistemática e filogenia do gênero Camptosema W.J.Hook. \& Arn. (Leguminosae: Papilionoideae: Phaseoleae). Tese de Doutorado. Universidade de São Paulo, São Paulo, 259p.

Radford, A. E.; Dickison, W. C.; Massey, J. R. \& Bell, C. R. 1974. Vascular plant systematics. Harper \& Row, New York, 891p.

Richards, P. W. 1952. The tropical rain forest: a ecological study. University Press, Cambridge, 450p.
Rodas, R. D. 1991. Estudo taxonômico do gênero Indigofera L. (Leguminosae) no Brasil e Paraguai. Dissertação de Mestrado. Universidade Federal do Rio de Janeiro, Rio de Janeiro, 196p.

Saporetti-Júnior, A. W. 2005. Composição florística e estrutural do componente arbóreo em um remanescente de Floresta Atlântica Montana, Araponga, MG. Dissertação de Mestrado. Universidade Federal de Viçosa, Viçosa, 84p.

Soares, M. P.; Saporetti-Junior, A. W.; Neto, J. A. A. M.; Silva, A. F. \& Souza, A. L. de 2006. Composição florística do estrato arbóreo de Floresta Atlântica interiorana em Araponga - Minas Gerais. Revista Árvore 30(5): 859-870.

Souza, V. C. \& Lorenzi, H. 2005. Botânica sistemática: guia ilustrado para identificação das famílias de angiospermas da flora brasileira, baseado em APG II. Nova Odessa: Instituto Plantarum, 640p.

Vanni, R. O. 2001. El género Desmodium (Leguminosae, Desmodieae) en Argentina. Darwiniana 39(3-4): 255-285.

Veloso, H. P.; Rangel Filho, A. L. R.; Lima, J. C. A. 1991. Classificação da vegetação brasileira, adaptada a um sistema universal. IBGE, Departamento de Recursos Naturais e Estudos Ambientais, Rio de Janeiro, 123p. 